\title{
Climate Change Impacts on Water Resources of Greater Zab River, Iraq
}

\author{
Nahlah Abbas ${ }^{1}$, Saleh A. Wasimi ${ }^{1}$ and Nadhir Al-Ansari ${ }^{2}$ \\ 1. School of Engineering and Technology, Central Queensland University, Melbourne 3000, Australia \\ 2. Geotechnical Engineering, Lulea University of Technology, Lulea 971 87, Sweden
}

\begin{abstract}
Greater Zab is the largest tributary of the Tigris River in Iraq where the catchment area is currently being plagued by water scarcity and pollution problems. Contemporary studies have revealed that blue and green waters of the basin have been manifesting increasing variability contributing to more severe droughts and floods apparently due to climate change. In order to gain greater appreciation of the impacts of climate change on water resources in the study area in near and distant future, SWAT (Soil and Water Assessment Tool) has been used. The model is first tested for its suitability in capturing the basin characteristics, and then, forecasts from six GCMs (general circulation models) with about half-a-century lead time to 2046 2064 and one-century lead time to 2080 2100 are incorporated to evaluate the impacts of climate change on water resources under three emission scenarios: A1B, A2 and B1. The results showed worsening water resources regime into the future.
\end{abstract}

Key words: Greater Zab, SWAT, sensitivity, blue water, green water.

\section{Introduction}

The water resources of a basin is impacted by a multitude of variables such as precipitation and other meteorological factors, vegetation and other land use, natural calamities such as hurricanes, and induced catastrophes such as bushfires. Changes in climate, population and land use have profound impacts on the supply and demand balance of future water resources and water availability at a global $[1,2]$ and regional scale $[3,4]$. Where the water resources are limited, the water balance is often delicate and the situation can easily aggravate by climate change [5] which can be unprecedented because the water system is vulnerable to climate change outside the range of historical events [6]. Climate change can considerably impact on the hydrological cycles mainly through the alteration of evapotranspiration and precipitation [7-9]. The effects can strikingly manifest as severe droughts or raging floods having a profound impact on the water balance

Corresponding author: Saleh A. Wasimi, associate professor, research fields: water resources planning and management and hydrology. of a basin [10].

Countries in the middle-east typically suffer from water shortages and the long-term predictions are rather ominous - more water shortages in both surface and groundwater resources in the future [11, 12]. Iraq fits the description of a typical middle-east country, and it is highly vulnerable to climate change [13]. The country can be classified as arid or semi-arid with less than $150 \mathrm{~mm}$ of annual rain and high evaporation rate. Its water balance is rather delicate threatened by water scarcity that can significantly exacerbate due to climate change $[12,13]$. Arguably, climate change is one of the greatest challenges confronting Iraq, its adverse effects on water resources can alter the environment and impact the economy, particularly the agricultural sector. Understandably, therefore, there is a strong demand from decision makers for predictions about the potential impacts of climate change on the duration and magnitude of precipitation, which have ramifications on sustaining and managing water resources appropriately and alleviating water scarcity problem that has become pronounced [12].

In northern Iraq, Greater Zab is the largest tributary 
of Tigris River in terms of its contribution to Tigris flow. Based on some estimates, Greater Zab contributes around $40 \% \sim 60 \%$ of total Tigris flow [14]. Further, it is the only source of surface water for Erbil City, the capital of Iraqi Kurdistan. This basin has been suffering from water scarcity and pollution [15]. So far, water issues related to climate change in the Greater Zab catchment have not been well addressed within climate change analyses and climate policy construction [16]. Therefore, the main objective of this study has been to assess the potential future climatic changes on the water sources of Greater Zab, specifically blue and green waters. The computer-based hydrological model SWAT (Soil and Water Assessment Tool) has been used to explore the effects of climatic change on stream flow of the study area. The model was set at monthly scale using available spatial and temporal data and calibrated against measured stream flow. Climate change scenarios were obtained from general circulation models.

\section{Materials and Methods}

\subsection{Study Area}

Greater Zab originates from the Ararat Mountains in

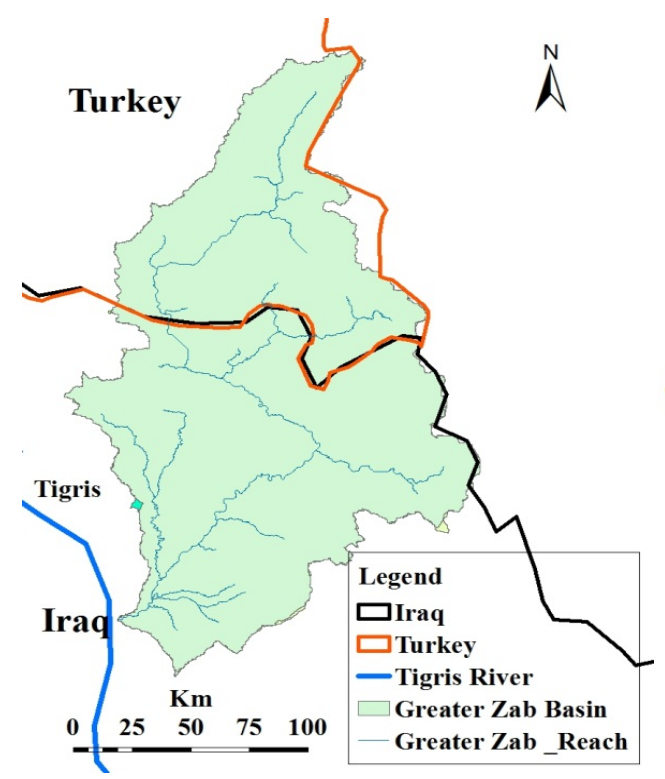

(a)
Turkey, runs through the central northern part of Iraq, and then, links with Tigris River south of Mosul City traversing a distance of $372 \mathrm{~km}$ (Fig. 1). Greater Zab and its tributaries namely Shamdinan, Haji Beg, Rawandooz and Khazir-Gormal rivers are located between latitudes $36^{\circ} \mathrm{N}$ and $38^{\circ} \mathrm{N}$, and longitudes $43.3^{\circ} \mathrm{E}$ and $44.3^{\circ} \mathrm{E}$ [15]. It drains an area of $26,473 \mathrm{~km}^{2}, 65 \%$ of which is located in Iraq and the remainder in Turkey [12]. Greater Zab basin is a mountainous area with elevation ranging from $180 \mathrm{~m}$ to $4,000 \mathrm{~m}$ above sea level (Fig. 1). There are many springs in the basins which are the main source for irrigation [17]. Mean annual temperature is $14.3{ }^{\circ} \mathrm{C}$ and mean annual precipitation is $570 \mathrm{~mm}$, ranging from $350 \mathrm{~mm}$ to $1,000 \mathrm{~mm}$. Most of the precipitation in the Greater Zab basin falls in winter and spring. Typically, the rainfall is distributed over the year: $48.9 \%$ including snowfall falls in winter, $37.5 \%$ in spring, $12.9 \%$ in autumn, and $0.57 \%$ in summer [17]. The flow regime of Greater Zab demonstrates highly seasonal flow with peak flow occurring in May and low seasonal flow from July to December. This is a typical near-natural nival regime, in which winter precipitation in the form of snow and snow-melt in the spring is dominant. So far no dam has been constructed

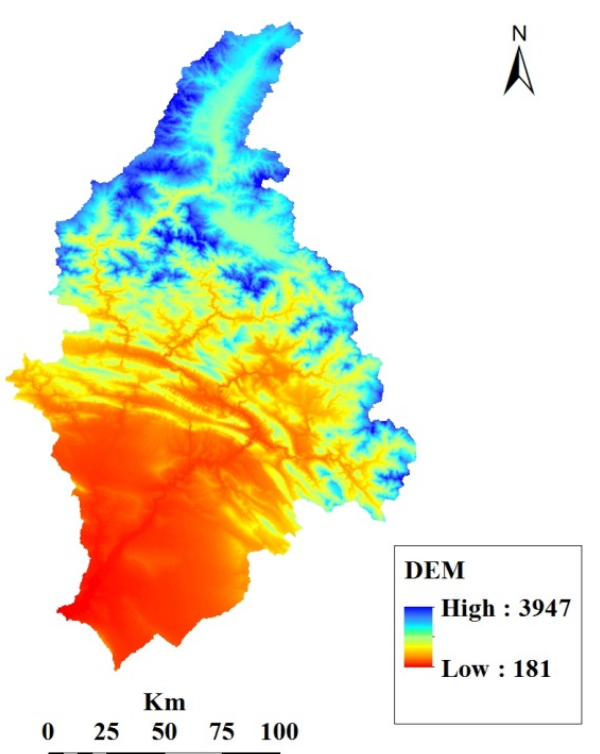

(b)

Fig. 1 Greater Zab basin: (a) the location; (b) DEM (digital elevation model). 
on the river, however, both countries (Turkey and Iraq) have plans to build dams on the river [14]. Seventy nine percent of the watershed is covered by pasture, and $21 \%$ of the land is used for different agricultural activities. There are three discharge stations namely, Bekhme, Bakrman and EskiKelek stations. Bekhme station lies at latitude $36.63^{\circ} \mathrm{N}$ and longitude $44.48^{\circ} \mathrm{E}$, northeast of the basin. Bakrman station is located near the Greater Zab outlet, at latitude $36.33^{\circ} \mathrm{N}$ and longitude $43.55^{\circ} \mathrm{E}$ at Khazir River, one of Greater Zab's tributaries. EskiKelek station is situated in the lower part of the basin, at the basin outlet, at latitude $36^{\circ} \mathrm{N}$ and longitude $43.35^{\circ} \mathrm{E}$.

\subsection{Description of SWAT model}

SWAT [18] is a river watershed scale, semi-distributed, and physically based continuous time (daily computational time step) mathematical model for analyzing hydrology and water quality at various watershed scales with varying soils, land use and management conditions on a long-term basis. The SWAT model was originally developed by the USDA (United States Department of Agriculture) and the ARS (Agricultural Research Service) at the Grassland, Soil and Water Research Laboratory in Temple, Texas, USA [19]. SWAT system is embedded within a geographic information system (ArcGIS interface), in which different spatial environmental data, including climate, soil, land cover and topographic characteristics can be integrated.

Two major divisions, land phase and routing phase, are conducted to simulate the hydrology of a watershed. The land phase of the hydrological cycle predicts the hydrological components including surface runoff, evapotranspiration, groundwater, lateral flow, ponds, tributary channels and return flow. The routing phase of the hydrological cycles is the movement of water, sediments, nutrients and organic chemicals via the channel network of the basin to the outlet [18]. In the land phase of the hydrological cycle, the simulation of the hydrological cycle is based on the water balance equation:

$$
\begin{gathered}
S W_{t}=S W_{0}+\sum_{i=1}^{n}\left(R_{\text {day }}-Q_{\text {surf }}-E_{a}\right. \\
\left.-W_{\text {seep }}-Q_{g w}\right)
\end{gathered}
$$

where, $S W_{t}$ is the final soil water content $(\mathrm{mm}), S W_{o}$ is the initial soil water content on day $i(\mathrm{~mm}), t$ is the time (days), $R_{\text {day }}$ is the amount of precipitation on day $i$ (mm), $Q_{\text {surf }}$ is the amount of surface runoff on day $i$ (mm), $E_{a}$ is the amount of evapotranspiration on day $i$ (mm), $W_{\text {seep }}$ is the amount of water entering the vadose zone from the soil profile on day $i(\mathrm{~mm})$, and $Q_{g w}$ is the amount of return flow on day $i(\mathrm{~mm})$.

The SWAT model enables users to estimate surface runoff through two methods; the SCS (soil conservation service) curve number procedure (SCS 1972 in Ref. [18] and the Green and Ampt infiltration method [20]). The SCS method has been used in this study due to non-availability of sub-daily data that is required by the Green and Ampt infiltration method. The model estimates the volume of lateral flow depending on the variation in conductivity, slope and soil water content. A kinematic storage model is utilized to predict lateral flow through each soil layer. Lateral flow occurs below the surface when the water rates in a layer exceed the field capacity after percolation. The groundwater simulation is divided into two aquifers which are a shallow aquifer (an unconfined) and a deep confined aquifer in each watershed. The shallow aquifer contributes to stream flow in the main channel of the watershed. Water that percolates into the confined aquifer is presumably contributing to stream flow outside the watershed. Three methods are provided by SWAT model to estimate potential evapotranspiration (PET); the Penman-Monteith method [21], the Priestley-Taylor method [22] and the Hargreaves method [23]. The Penman-Monteith method requires air temperature, wind-speed, solar radiation and relative humidity; Priestley-Taylor method needs air temperature and solar radiation, while Hargreaves method needs only daily temperature as inputs. Water 
is routed through the channel network by applying either the variable storage routing or Muskingum River routing methods using the daily time step.

\subsection{Model Input}

Enormous amount of input data is required by SWAT to fulfill the tasks envisaged in this research. Basic data requirements for modelling include DEM (digital elevation model), land use map and soil map, weather data and discharge data. DEM was extracted from ASTER Global Digital Elevation Model (ASTERGDM) with a $30 \mathrm{~m}$ grid and $1 \times 1$ degree tiles. ${ }^{1}$ The land cover map was obtained from the European Environment Agency $^{2}$ with a $250 \mathrm{~m}$ grid raster for the year 2000. The soil map was collected from the global soil map of the Food and Agriculture Organization of the United Nations [24]. Weather data which includes daily precipitation, 0.5 hourly precipitations, maximum and minimum temperatures were obtained from the Iraq's Bureau of Meteorology. Monthly stream flow was collected from the Iraqi Ministry of Water Resources/National Water Centre.

\subsection{Model Setup}

In SWAT, the watershed is divided into sub-basins based on the DEM. The land use map, soil map and slope datasets are embedded with the SWAT databases. Thereafter, sub-basins are further delineated by HRUs (hydrologic response units). HRUs are defined as packages of land that have a unique slope, soil and land use area within the borders of the sub-basin. HRUs enable the user to identify the differences in hydrologic conditions such as evapotranspiration for varied soils and land uses. Routing of water and pollutants are predicted from the HRUs to the sub-basin level and then through the river system to the watershed outlet.

\subsection{Model Calibration and Validation}

\subsubsection{SUFI-2 Algorithm Description}

\footnotetext{
${ }^{1}$ http://gdem.ersdac.jspacesystems.or.jp/tile_list.jsp.

${ }^{2} \mathrm{http}$ ///www.eea.europa.eu/data-and-maps/data/global-land-cov er- $250 \mathrm{~m}$.
}

To evaluate the performance of SWAT, the sequential uncertainty fitting algorithm application (SUFI-2) embedded in the SWAT-CUP package [25] was used. The advantages of SUFI-2 are that it combines optimization and uncertainty analysis, can handle a large number of parameters through Latin hypercube sampling, and it is easy to apply [25]. Furthermore, as compared with other different techniques used in SWAT such as generalized GLU (likelihood uncertainty estimation), parameter solution (parsol), MCMC (Markov chain Monte Carlo), SUFI-2 algorithm was found to obtain good prediction uncertainty ranges with a few number of runs [26]. This efficiency is of great significance when implementing complex and large-scale models [27].

The SUFI-2 first identifies the range for each parameter. After that, Latin hypercube method is used to generate multiple combinations among the calibration parameters. Finally, the model runs with each combination and the obtained results are compared with observed data until the optimum objective function is achieved. Since the uncertainty in forcing inputs (e.g., temperature, rainfall), conceptual model and measured data are not avoidable in hydrological models, the SUFI-2 algorithm computes the uncertainty of the measurements, the conceptual model and the parameters by two measures: $P$-factor and $R$-factor. P-factor is the percentage of data covered by the $95 \%$ PPU (prediction uncertainty) which is quantified at $2.5 \%$ and $97.5 \%$ of the cumulative distribution of an output variable obtained through Latin hypercube sampling [25]. The $R$-factor is the average width of the 95 PPU divided by the standard deviation of the corresponding measured variable. In an ideal situation, $P$-factor tends towards 1 and $R$-factor to zero [25]. The objective of the algorithm is to increase $P$-factor and reduce $R$-factor in order to achieve the optimal parameter range. These factors together reflect the strength of the calibration-uncertainty analysis. Further, SUFI-2 calculates the coefficient of determination $\left(R^{2}\right)$ and the 
ENC (Nasch-Sutcliff efficiency) [28] to assess the goodness of fit between the measured and simulated data. $R^{2}$ shows the strength of the relationship between the simulated and observed data. It ranges from 0 to 1 [29]. The higher values of $R^{2}$ reflect less error variance, and values greater than 0.5 are satisfactory [30]. $R^{2}$ has been widely used to provide an assessment of climate change detection, hydrological and hydroclimatological applications $[29,31,32] . R^{2}$ is given by

$$
R^{2}=\left[\frac{\sum_{i=1}^{n}\left(O_{i}-\bar{O}\right)\left(P_{i}-\bar{P}\right)}{\left[\sum_{i=1}^{n}\left(O_{i}-\bar{O}\right)^{2}\right]^{0.5}\left[\sum_{i=1}^{n}\left(P_{i}-\bar{P}\right)^{2}\right]^{0.5}}\right]^{2}
$$

where, $O_{i}$ is the observed stream flow, $P_{i}$ is the simulated stream flow, $\bar{O}$ is the mean observed stream flow during the evaluation period and $\bar{P}$ is the mean simulated stream flow for the same period.

The $E N C$ value is an indication of how well the plot of the observed against the simulated values fits the 1:1 line. It can range from negative infinity $(-\infty)$ to one. The closer the value to one, the better the prediction is, while the value of less than 0.5 indicates unsatisfactory model performance [30]. ENC is calculated as shown below:

$$
E N C=1-\left[\frac{\sum_{i=1}^{n}\left(O_{i}-P_{i}\right)^{2}}{\sum_{i=1}^{n}\left(O_{i}-\bar{O}\right)^{2}}\right]
$$

$E N C$ was recommended to be used for calibration for two reasons. First, it has been adopted by ASCE [33] and second, Gegates et al. [29] recommend it due to its straightforward physical interpretation [34]. Besides, it has found wide applications offering extensive information on reported values [31].

SUFI-2 enables users to conduct global sensitivity analysis, which is computed based on the Latin hypercube and multiple regression analysis. The multiple regression equation is defined as below:

$$
g=\alpha+\sum_{i=1}^{m} \beta_{i} * b_{i}
$$

where, $g$ is the value of evaluation index for the model simulations, $\alpha$ is a constant in multiple linear regression equation, $\beta$ is the coefficient of the regression equation, $b$ is a parameter generated by the Latin hypercube method and $m$ is the number of parameters.

The $t$-stat of this equation which indicates parameter sensitivity is applied to determine the relative significance for each parameter [35], the more the sensitive parameter, the greater is the absolute value of the $t$-stat [25]. $P$-value is an indication of the significance of the sensitivity, $P$-value close to zero has more significance.

\subsection{GCM (General Circulation Model) inputs}

Six GCMs from CMIP3 namely CGCM3.1/T47, CNRM-CM3, GFDL-CM2.1, IPSLCM4, MIROC3.2 (medres) and MRI CGCM2.3.2 were selected for climate change projections in the Lesser Zab basin under a very high emission scenario (A2), a medium emission scenario (A1B) and a low emission scenario (B1) for two future periods (2046 2064) and (2080 2100). The projected temperatures and precipitation were then inputted to the SWAT model to compare water resources in the basin with the baseline period (1980 2010). Fig. 2 captures the outputs from the models, where blue water refers to freshwater in rivers, lakes, and aquifers and green water refers to the part of precipitation that is held by soil and vegetation which eventually returns to atmosphere through evapotranspiration. BCSD method was used to downscale the GCM results [36].

\section{Results and Discussion}

\subsection{Sensitivity Analysis}

Sensitivity analysis has been carried out for 25 parameters related to stream flow (Table 1), from which 12 most sensitive parameters have been considered, as is the usual practice, for implementing model calibration for the Greater Zab basin.

The ranking of 12 highest sensitive parameters for the watershed is presented in Table 2. For Greater Zab, SFTMP was the most sensitive parameter. This is reasonable result as Greater $\mathrm{Zab}$ is a snow-dominated 


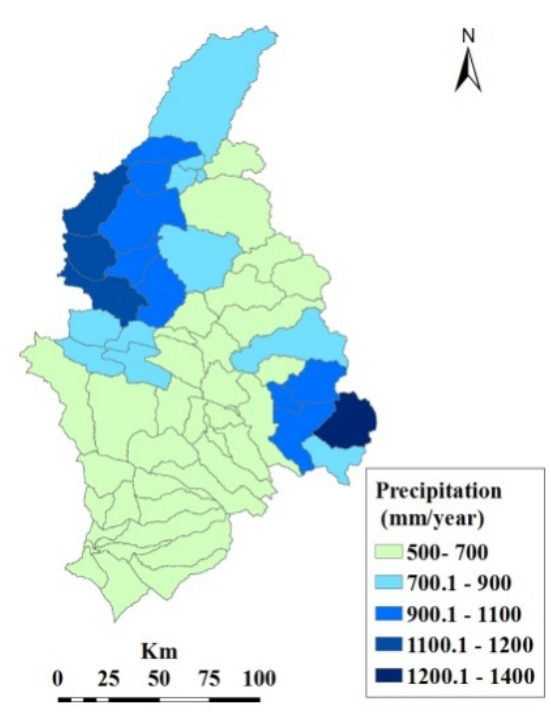

(a)

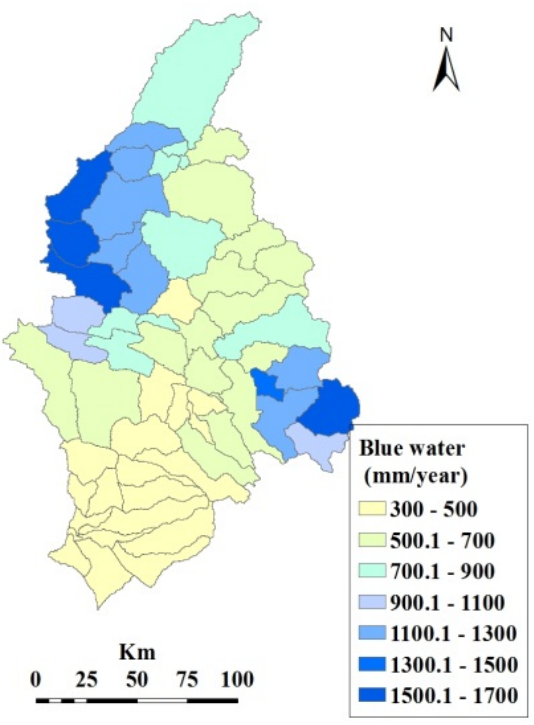

(b)

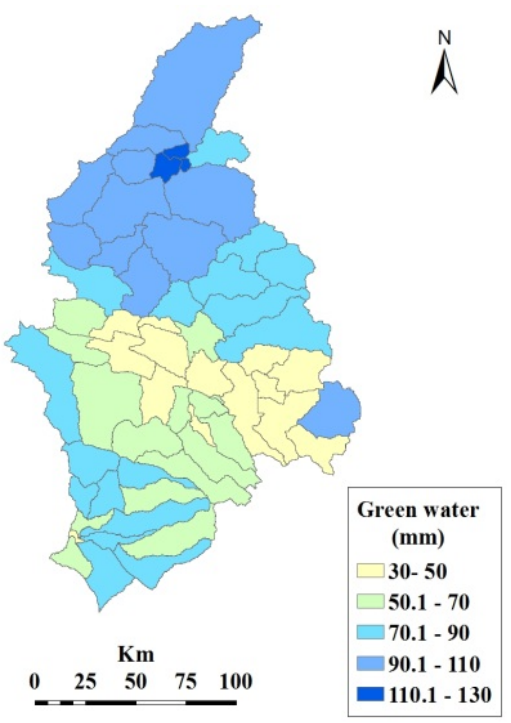

(c)

Fig. 2 For the baseline period of 1980 2010: (a) average of precipitation; (b) average of blue water; (c) average of green water storage.

Table 1 Description of input parameters of stream flow selected for model calibration.

\begin{tabular}{|c|c|c|c|}
\hline Group & Parameter & Description & Unit \\
\hline \multirow{4}{*}{ Soil } & $S O L \_A L B$ & Moist soil albedo & - \\
\hline & $S O L \_A W C$ & Available water capacity & $\mathrm{mm} \cdot \mathrm{mm}^{-1}$ \\
\hline & $S O L \_K$ & Saturated hydraulic conductivity & $\mathrm{mm} \cdot \mathrm{h}^{-1}$ \\
\hline & $S O L \_Z$ & Depth to bottom of second soil layer & $\mathrm{mm}$ \\
\hline \multirow{5}{*}{ Groundwater } & ALPHA_BF & Base flow alpha factor & day \\
\hline & GW_DELAY & Groundwater delay & day \\
\hline & GW_REVAP & Groundwater "revap" coefficient & - \\
\hline & $G W Q M N$ & Threshold depth of water in the shallow aquifer for return flow to occur & $\mathrm{mm} \cdot \mathrm{H}_{2} \mathrm{O}$ \\
\hline & REVAPMN & Threshold depth of water in the shallow aquifer for "revap" to occur & $\mathrm{mm} \cdot \mathrm{H}_{2} \mathrm{O}$ \\
\hline Subbasin & TLAPS & Temperature laps rate & ${ }^{\circ} \mathrm{C} \cdot \mathrm{km}^{-1}$ \\
\hline \multirow{4}{*}{$\mathrm{HRU}$} & $E P C O$ & Soil evaporation compensation factor & - \\
\hline & ESCO & Plant uptake compensation factor & - \\
\hline & CANMX & Maximum canopy storage & $\mathrm{mm} \cdot \mathrm{H}_{2} \mathrm{O}$ \\
\hline & SLSUBBSN & Average slope length & $\mathrm{m}$ \\
\hline \multirow{2}{*}{ Routing } & $\underline{\mathrm{CH}} \_\mathrm{N} 2$ & Manning's $n$ value for the main channel & - \\
\hline & CH_K2 & Effective hydraulic conductivity in main channel alluvium & $\mathrm{mm} \cdot \mathrm{h}^{-1}$ \\
\hline \multirow{2}{*}{ Management } & BIOMIX & Biological mixing efficiency & - \\
\hline & $C N 2$ & Initial SCS runoff curve number for moisture condition II & - \\
\hline \multirow{7}{*}{ General data basin } & $\underline{\text { SFTMP }}$ & Snowfall temperature & ${ }^{\circ} \mathrm{C}$ \\
\hline & $S M F M N$ & Minimum melt rate for snow during year & $\mathrm{mm} \cdot \mathrm{H}_{2} \mathrm{O} \cdot{ }^{\circ} \mathrm{C}^{-1} \cdot$ day $^{-1}$ \\
\hline & SMFMX & Maximum melt rate for snow during year & $\mathrm{mm} \cdot \mathrm{H}_{2} \mathrm{O}^{\circ} \mathrm{C}^{-1} \cdot$ day $^{-1}$ \\
\hline & TEMP & Snow pack temperature lag factor & - \\
\hline & SURLAG & Surface runoff lag time & day \\
\hline & $B L A I$ & Maximum potential leaf area index for land cover/plant & - \\
\hline & SLOPE & Slope & - \\
\hline
\end{tabular}


Table 2 Ranking of 12 highest sensitive parameters related to stream flow in the two basins.

\begin{tabular}{llll}
\hline Parameter & Ranking & Initial values & Fitted values \\
\hline SFTMP & 1 & $-5 \sim 5$ & 3.5475 \\
ALPHA_BF & 2 & $0 \sim 1$ & 0.032500 \\
CN2 & 3 & $-0.2 \sim 0.2$ & -0.175 \\
SOL_AWC & 4 & $-0.2 \sim 0.4$ & 0.052 \\
HRU_SLP & 5 & $0 \sim 0.2$ & 0.05650 \\
SLSUBBSN & 6 & $0 \sim 0.2$ & 0.15450 \\
SURLAG & 7 & $0.05 \sim 24$ & 17.4 \\
ESCO.hru & 8 & $0 \sim 0.2$ & 0.85850 \\
GWQMN & 9 & $0 \sim 2$ & 1.155000 \\
CH_K2 & 10 & $5 \sim 130$ & 76.87 \\
GW_REVAP & 11 & $0 \sim 0.2$ & 0.179500 \\
GW_DELAY & 12 & $30 \sim 450$ & 35.25 \\
\hline
\end{tabular}

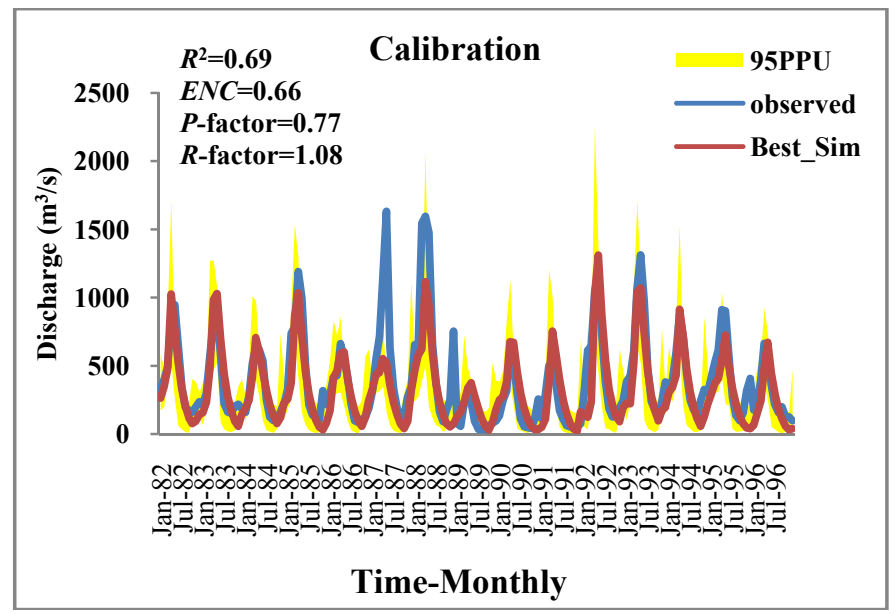

(a)

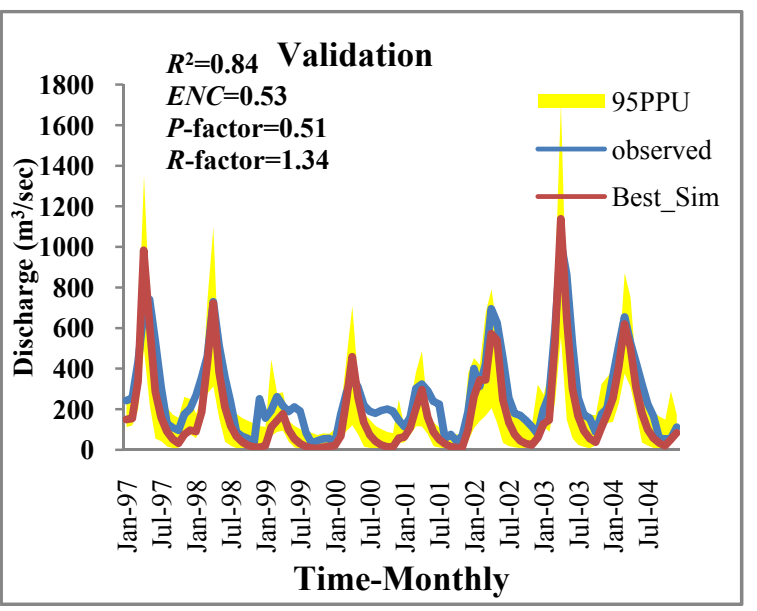

(b)

Fig. 3 The SWAT model at monthly scale at Bekame station: (a) calibration; (b) validation.

mountainous basin. Among the groundwater related parameters, $A L P H A-B E$ was observed to be the most sensitive parameter which was ranked as the second. This result is consistent with the finding of $\mathrm{Li}$ et al. [37], who found that $A L P H A$ is a highly sensitive groundwater parameter during SWAT calibration. CN2 was ranked the third. In most SWAT applications in different watersheds, $C N 2$ was found to be the most sensitive parameter [38]. SOL_AWC came the fourth.

\subsection{Calibration and Validation}

SWAT was calibrated and validated for Greater Zab basin at three discharge stations on a monthly scale (Bekhme station, Bakrmanstation and EskiKelek station). The model was calibrated for 18 years (1979 1996) and validated for 8 years (1997 2004), the first three years was set as a warm up.

The results of monthly discharge calibration and validation for the three stations showed good agreement with observed data as shown in Figs. 3-5. The highest $R^{2}$ and $E N C$ were obtained for EskiKelek Station during the calibration and validation processes (Fig. 5), where $R^{2}$ and $E N C$ were 0.77 and 0.70 , respectively, during the calibration. $R^{2}$ increased to 0.89 and $E N C$ decreased to 0.66 during the validation. This is because of the fact that EskiLelek station is located at the outlet of the basin and the model is calibrated from upstream to downstream [25]. The calibrated parameters of upstream stations contribute partially to the calibration process of downstream stations [26], thus enhancing simulation results of downstream EskiKelek station. 


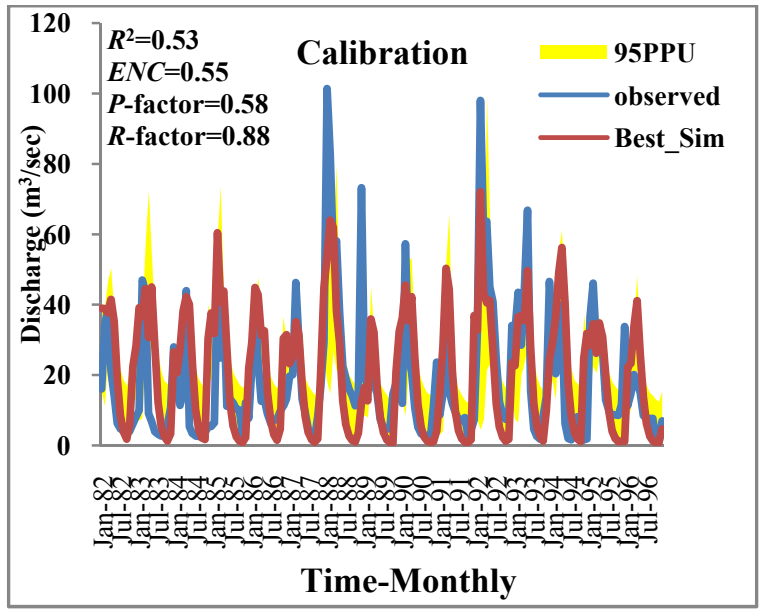

(a)

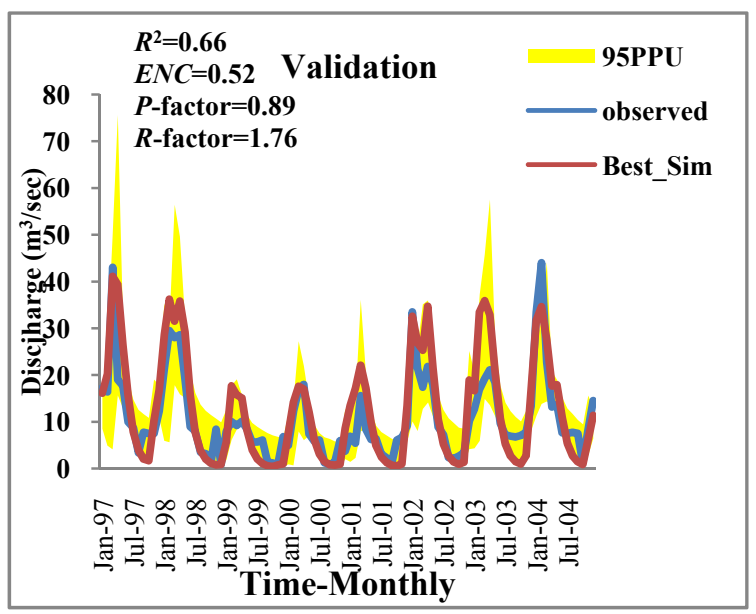

(b)

Fig. 4 The SWAT model at monthly scale at Bakrman station: (a) calibration; (b) validation.
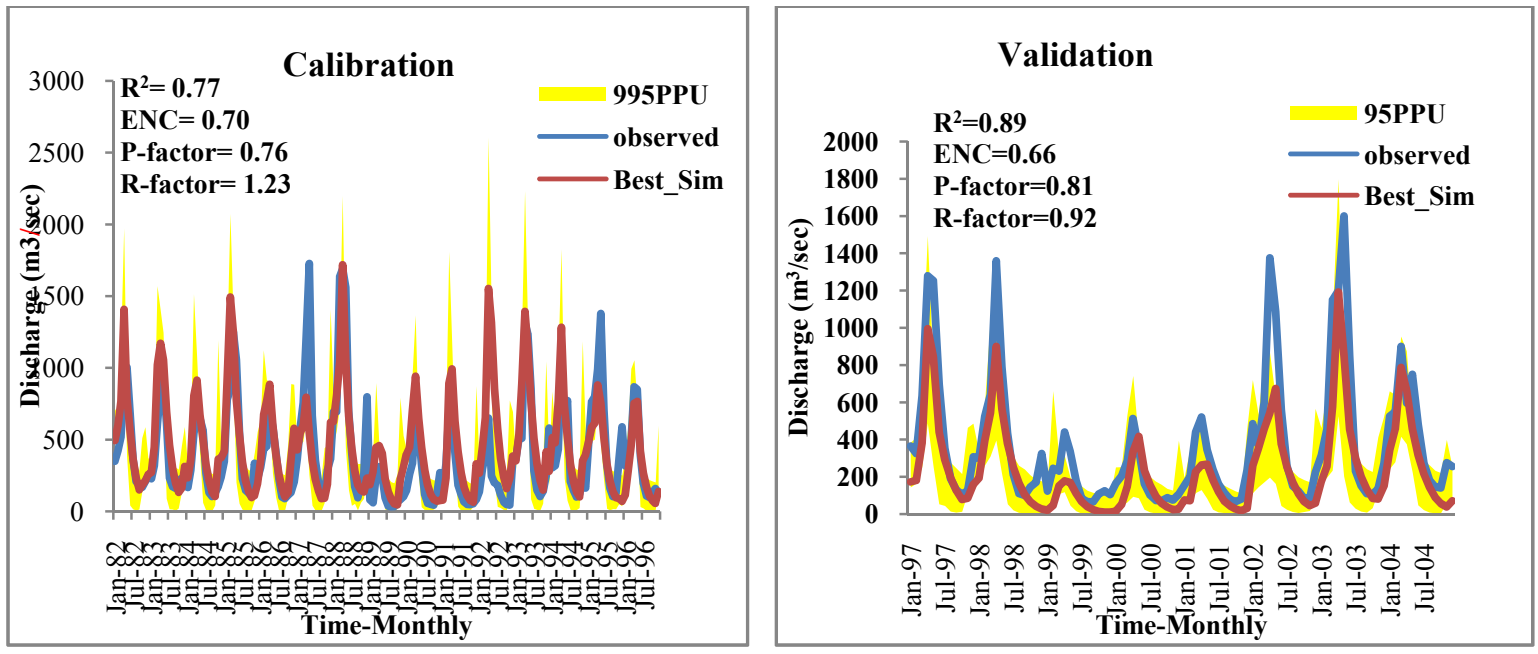

Fig. 5 The SWAT model at monthly scale at EskiKelek: (a) calibration; (b) validation.

3.2.1 Trends in Precipitation, Blue Water, Green Water, Storage and Water Flow in the Past

Using the calibrated model, annual precipitation, blue water (summation of water yield and deep aquifer recharge) and green water storage (soil water content) and green water flow (evapotranspiration) were estimated during the last three decades to identify the impacts of climate change on the water cycle components. Blue water is the freshwater humans can access for instream use or withdrawal. Green water storage does not provide direct access to humans but sustains natural flora and rain-fed agriculture. Green water flow is actual evapotranspiration. The model outputs matched observations.
Fig. 6 captures the spatial distribution of precipitation in HRUs over three consecutive decades. Generally, precipitation decreased from upstream to downstream and from the east to the west of the basin. This is because the upper and east part of the basin is mountainous, experiencing higher precipitation and snowfall compared to the lower and western part of the basin which is rather flat and experiencing less snowfall. From Fig. 6, it is apparent that there is a general declining trend in precipitation over time. The 1990s and 2000s decades experienced decreases by about $21 \%$ and $32 \%$ compared to 1980 s decade, respectively (Table 3). 


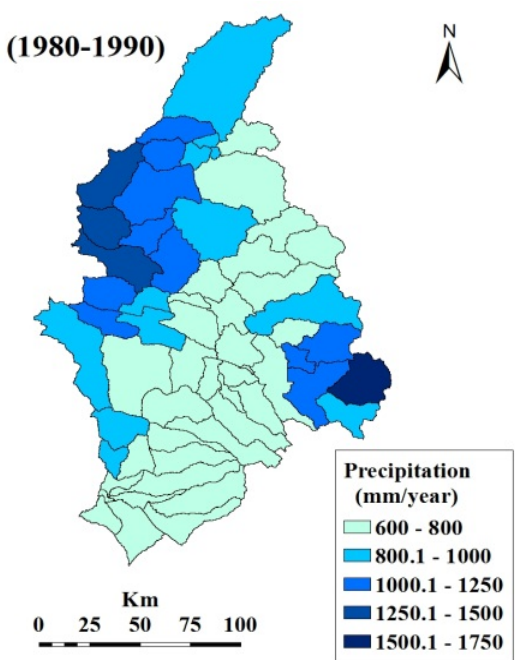

(a)

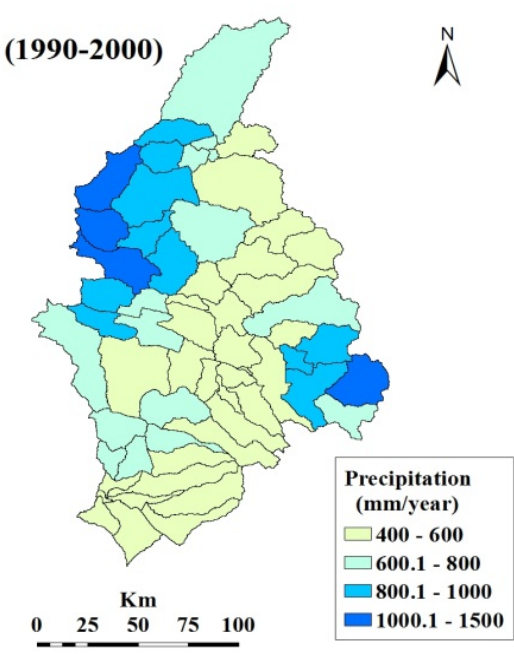

(b)

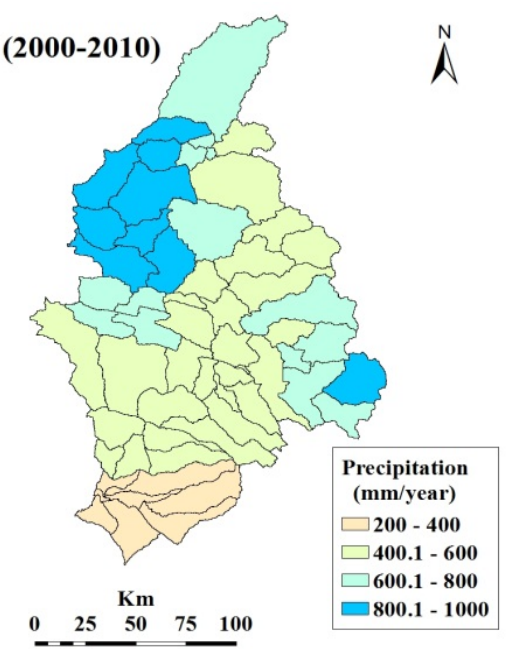

(c)

Fig. 6 Spatial distribution of precipitation in the Greater Zab basin over three consecutive decades: (a) 1980 1990; (b) 1990 2000; (c) 2000 2010.

Table 3 Relative changes in precipitation, blue water and green water in the Lesser Zab basin over three decades.

\begin{tabular}{llll}
\hline \multirow{2}{*}{ Water component } & \multicolumn{3}{c}{ Rate of relative change in the last three decades } \\
\cline { 2 - 4 } & 1990 s vs. 1980s & $2000 \mathrm{~s}$ vs. 1990s & $2000 \mathrm{~s}$ vs. 1980s \\
\hline Precipitation & -0.21 & -0.14 & -0.32 \\
Blue water & -0.29 & -0.25 & -0.46 \\
Green water storage & -0.12 & -0.06 & -0.17 \\
Green water flow & -0.06 & -0.04 & -0.05 \\
\hline
\end{tabular}

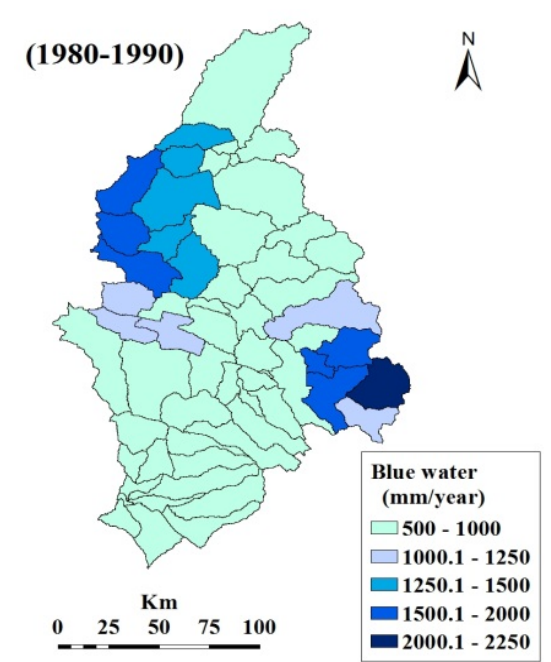

(a)

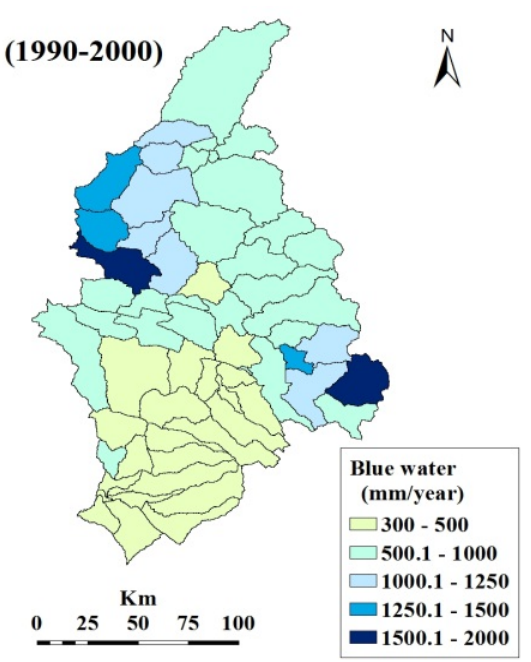

(b)

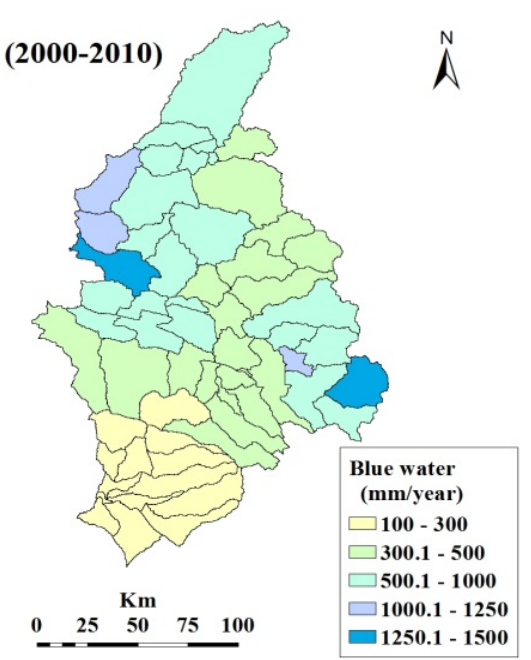

(c)

Fig. 7 Spatial distribution of blue water in the Greater Zab basin over three consecutive decades.

Blue water and green water storage in the Greater Zab basin decreased from upstream to downstream (Figs. 7 and 8). Generally, green water tracks blue water, where blue water flows are high, green water flows also have a tendency to be high. The spatial patterns of the blue and green water flows are largely influenced by the spatial patterns of precipitation. Land cover also influences the forming of spatial patterns. The average annual blue water and green water storage for the entire catchment significantly 

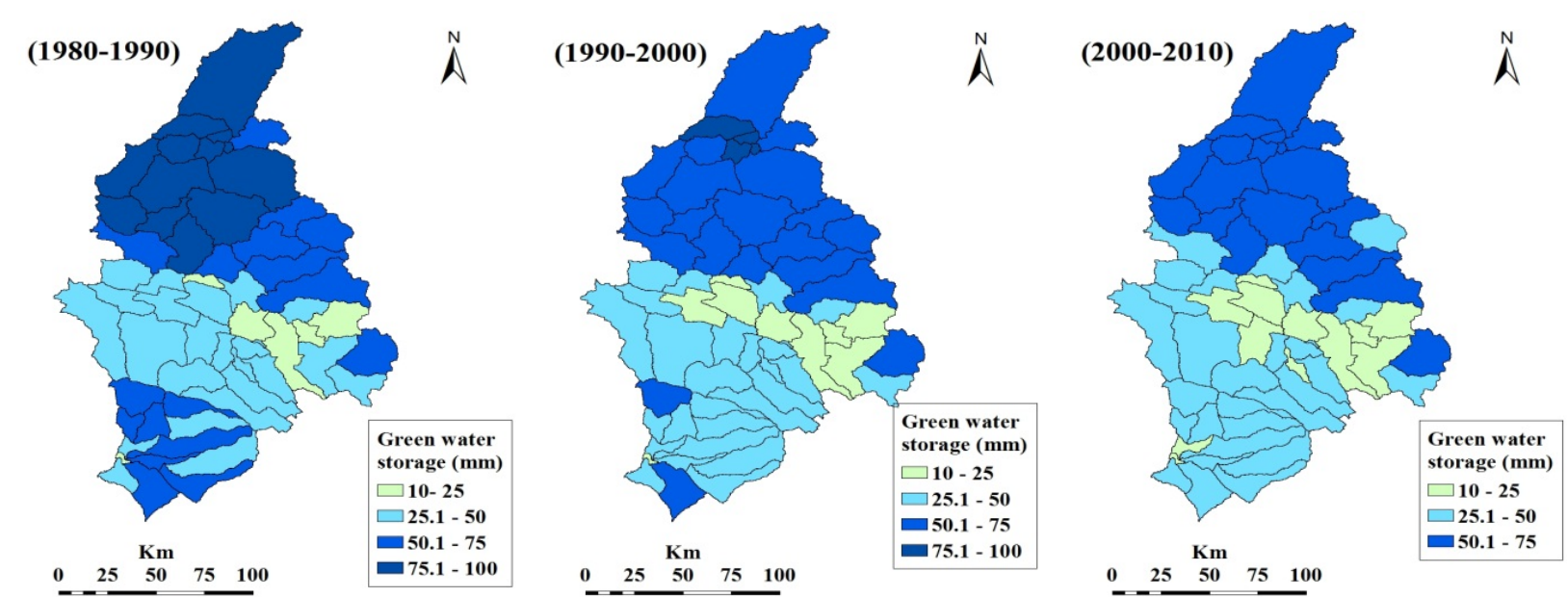

Fig. 8 Spatial distribution of green water storage in the Greater Zab basin over three consecutive decades: (a) 1980 1990; (b) 1990 2000; (c) 2000 2010.

decreased from 1980s to 2000s. It is possible that the decreasing trends in the average annual blue water and green water are attributable to climate change. Green water flow was relatively stable during the entire period (Table 3) due to the assumption that land cover/land use remained unchanged during the period of 1980 to 2010.

\subsection{Blue Water Scarcity Indicators}

The calibrated model was used for water scarcity analysis. Among a large number of water scarcity indicators, the most widely applied and accepted is the water stress threshold [39], defined as $1,700 \mathrm{~m}^{3} \cdot$ capita $^{-1} \cdot$ year $^{-1}$ introduced by Falkenmark [40], which was used in this study. The $1,700 \mathrm{~m}^{3} \cdot$ capita $^{-1} \cdot$ year $^{-1}$ is calculated based on estimations of water needs in the household, agriculture, industry and energy sectors, and the demand of the environment [39]. A value equal or greater than $1,700 \mathrm{~m}^{3} \cdot$ capita $^{-1} \cdot$ year $^{-1}$ is considered as adequate to meet water demands. When water supply drops below $1,000 \mathrm{~m}^{3} \cdot$ capita $^{-1} \cdot$ year $^{-1}$, it is referred to as water scarcity and below $500 \mathrm{~m}^{3} \cdot$ capita $^{-1} \cdot$ year $^{-1}$ is extreme scarcity. The water availability per capita and water stress indicators were estimated for each of the 61 sub-basins of the Greater Zab catchment using the 2.5 arcmin population map available from the CIESIN
(Center for International Earth Science) Gridded Population of the World (GPW, version 3) ${ }^{3}$ for 2005. Fig. 9 demonstrates the spatial distribution of water resources per capita per year during the period of 1980 2010 based on the population estimates of the year of 2005. In general, up to $55 \%$ of the basin area, mostly located in the lower part of the basin, experienced extreme water scarcity. Twenty four percent of the basin experienced between $1000 \mathrm{~m}^{3}$ and 500 per capita per year. Seven percent only experienced sufficient blue water located in the upper part of the basin.

3.3.1 Uncertainty and Natural Variation in Green Water Storage

For the rain-fed agriculture, the average of the months per year for the period of 1980 to 2010 where green water storage is available (defined as $>1 \mathrm{~mm} \cdot \mathrm{m}^{-1}$ ) is of greatest importance [41]. This is shown in Fig. $10 \mathrm{a}$ - up to $65 \%$ of the basin experienced 7 to 8 months (October to May) in which green water was not depleted. The standard deviation $(S D)$ of the months per year without depleted soil water is presented for the 1980 2010 period in Fig. 10b. The areas with a high $S D$ such as the lower part of the basin show high variability in green water storage availability. This may result in reduced crop yield. In

\footnotetext{
${ }^{3}$ http://sedac.ciesin.columbia. edu/gpw.
} 


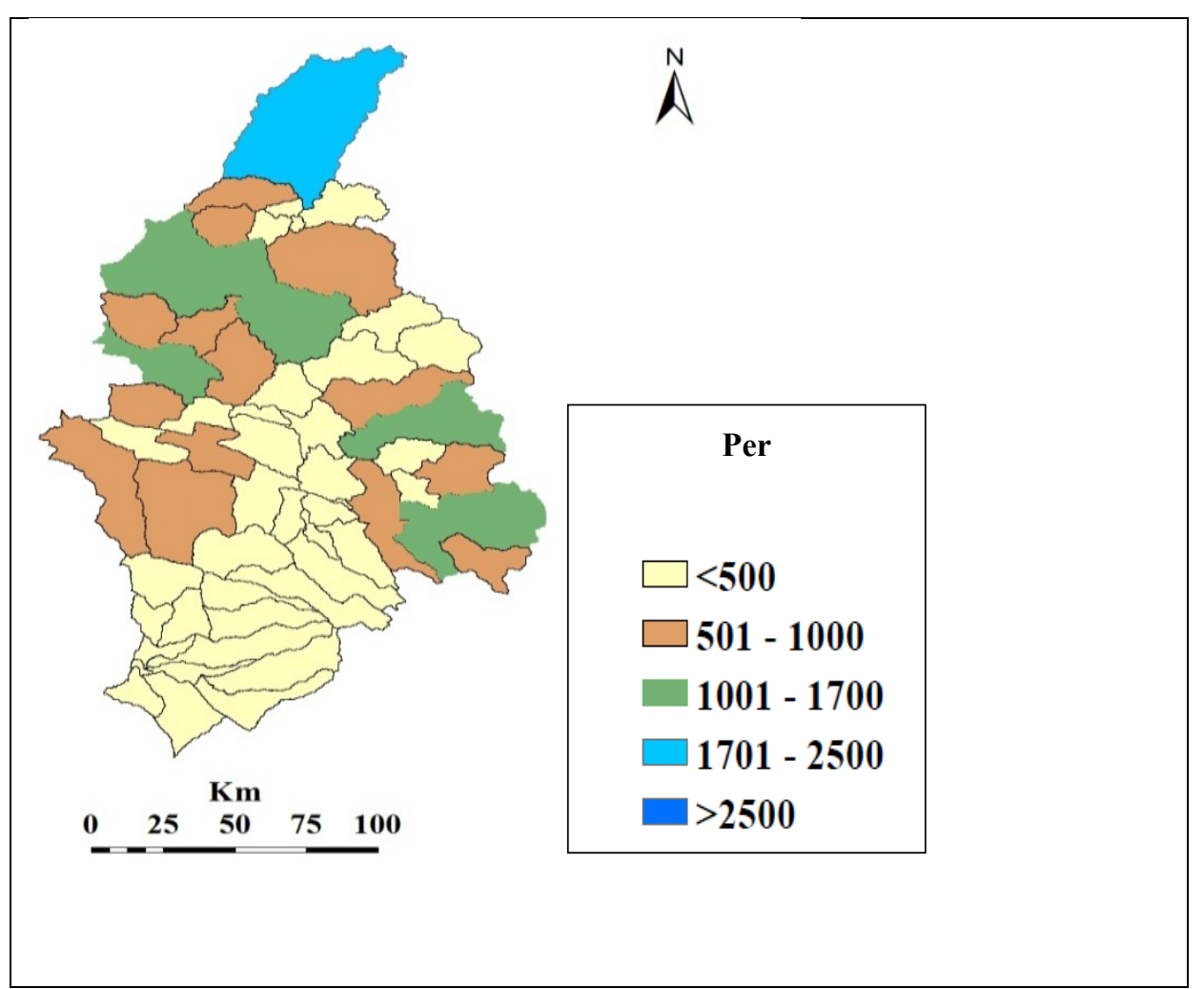

Fig. 9 Water scarcity in each modeled Greater Zab sub-basin represented by the modeled 1980 to 2010 annual average blue water flow availability per capita per year (using population of 2005) the average (Avg.) value of the 95PPU range.
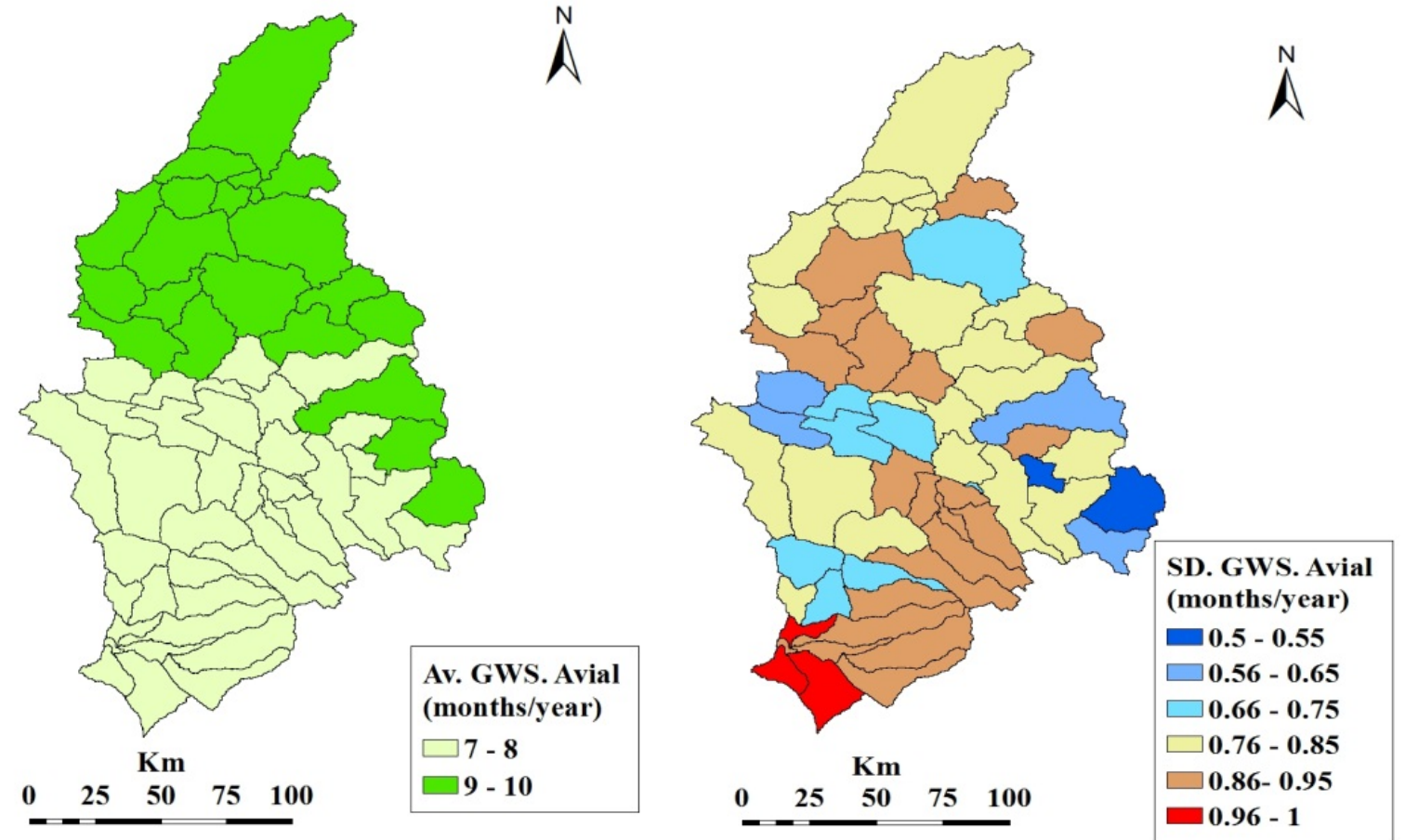

Fig. 10 The number of months per year where the GW-S (green water storage)is available for usage: (a) the $1980 \sim 2010$ average (Av.); (b) standard deviation (SD). 
order to sustain agriculture production in this part, adjusting irrigation systems and alternative cropping practices are highly recommended.

\subsection{The Impacts of Climate Change on Temperature and Precipitation}

Mean annual temperature and precipitation outputs from the six GCMs identified earlier were processed for the Greater Zab basin under three scenarios (A2, A1B, B1). Table 4 captures the projected changes in mean annual temperature for two future periods (2046 2064) and (2080 2100) relative to base period (1980 2010). Changes in mean temperature tend to be more consistent than precipitation. All the models showed steady increasing trends in temperature. GFDL (Geophysical Fluid Dynamics Laboratory) model projected the highest increases in mean temperature; however MRI (Meteorological Research Institute) predicted the lowest increases. Mean temperature of six models would increase by about 2.6 ${ }^{\circ} \mathrm{C}, 2.2{ }^{\circ} \mathrm{C}$ and $1.3{ }^{\circ} \mathrm{C}$ under $\mathrm{A} 2, \mathrm{~A} 1 \mathrm{~B}$ and $\mathrm{B} 1$, respectively, for near future (2046 2064). For distant future, the mean temperature would increase by $5{ }^{\circ} \mathrm{C}$, $4.3{ }^{\circ} \mathrm{C}$ and $1.55^{\circ} \mathrm{C}$ for $\mathrm{A} 2, \mathrm{~A} 1 \mathrm{~B}$ and $\mathrm{B} 1$ scenarios, respectively. Changes in mean temperature modify evapotranspiration and precipitation and hence blue water and green water flows.

Generally, all models showed a decrease in mean annual precipitation at half-a-century future (2046 2064) and one-century future (2080 2100) except MRI CGCM2.3.2. GFDL yielded highest decreases (Table 5). Fig. 11 shows the anomaly maps of precipitation distribution (maps of percent deviation from historic data, 1980 2010) for A2, A1B and B1 scenarios for the periods 2046 2064 and 2080 2100 for the average change of multi-GCM ensemble. A2 emission scenario produced the highest decreases while $\mathrm{B} 1$ emission scenario gave the lowest reductions

Table 4 GCM predicted changes in the mean annual temperature of the future under A2, A1B and B1 scenarios.

\begin{tabular}{|c|c|c|c|c|c|c|}
\hline \multirow{2}{*}{ Periods } & \multicolumn{6}{|c|}{ Annual change in mean temperature $\left({ }^{\circ} \mathrm{C}\right)$} \\
\hline & CGCM3.1/T47 & CNRM-CM3 & GFDL-CM2.1 & PSLCM4 & MIROC3.2 & MRI CGCM2.3.2 \\
\hline \multicolumn{7}{|l|}{$\mathrm{A} 2$} \\
\hline $2046 \sim 2064$ & 2.53 & 2.6 & 3 & 3.2 & 2.7 & 1.6 \\
\hline $2080 \sim 2100$ & 5.15 & 5.5 & 5.6 & 4.7 & 5.2 & 4.3 \\
\hline \multicolumn{7}{|l|}{ A1B } \\
\hline $2046 \sim 2064$ & 2.16 & 2 & 2.4 & 3 & 1.8 & 1.8 \\
\hline 2080 2100 & 4.29 & 4.6 & 4.7 & 4.6 & 4.2 & 3.4 \\
\hline \multicolumn{7}{|l|}{$\mathrm{B} 1$} \\
\hline 2046 2064 & 1.3 & 1.2 & 1.7 & 1.3 & 1.6 & 0.9 \\
\hline 2080 2100 & 1.5 & 1.5 & 1.7 & 1.6 & 1.5 & 1.5 \\
\hline
\end{tabular}

Table 5 GCM predicted changes in the mean annual precipitation of the future under A2,A1B and B1 scenarios.

\begin{tabular}{lllllll}
\hline \multirow{2}{*}{ Periods } & \multicolumn{5}{c}{ Annual change in precipitation (\%) } \\
\cline { 2 - 7 } & CGCM3.1/T47 & CNRM-CM3 & GFDL-CM2.1 & PSLCM4 & MIROC3.2 & MRI CGCM2.3.2 \\
\hline A2 & -0.19 & -0.28 & -0.18 & -0.18 & -0.18 & 0.012 \\
\hline $2046 \sim 2064$ & -0.22 & -0.12 & -0.35 & -0.26 & -0.28 & -0.11 \\
\hline A1B & & & & -0.11 & 0 \\
\hline $2046 \sim 2064$ & -0.03 & -0.10 & -0.17 & -0.23 & -0.22 & 0.13 \\
2080 2100 & -0.09 & -0.18 & -0.25 & & -0.10 & 0.09 \\
\hline B1 & & & -0.07 & -0.14 & 0.07 \\
\hline $2046 \sim 2064$ & 0.02 & -0.04 & -0.15 & -0.05 & & 0.04 \\
$2080 \sim 2100$ & -0.09 & -0.06 & &
\end{tabular}




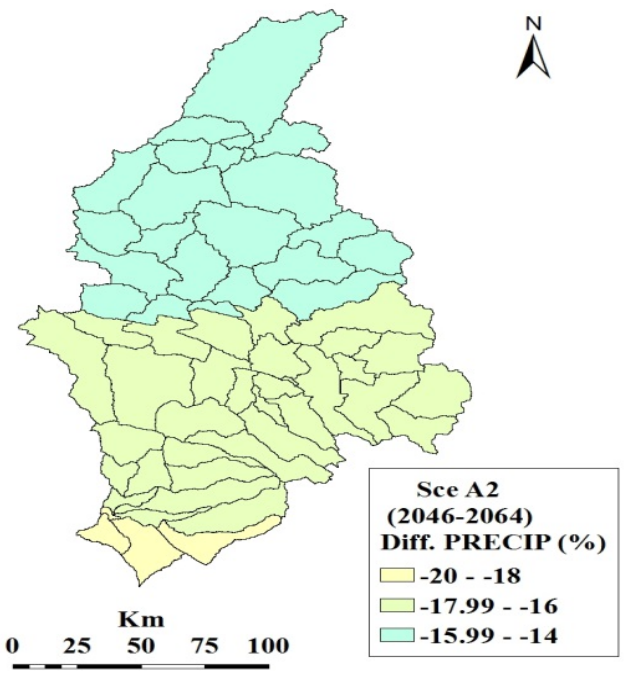

(a)

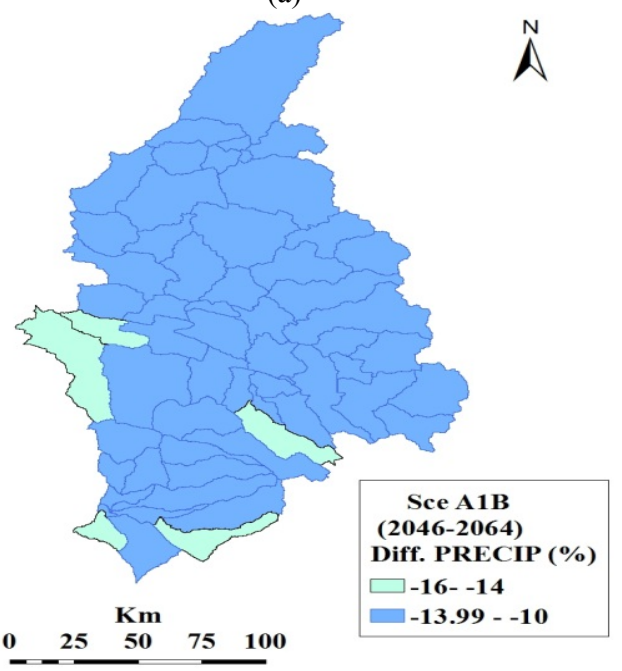

(c)

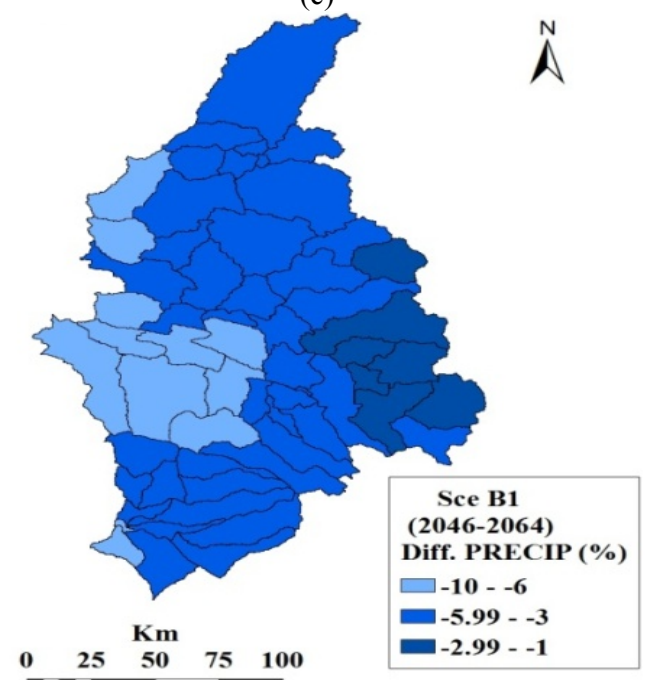

(e)

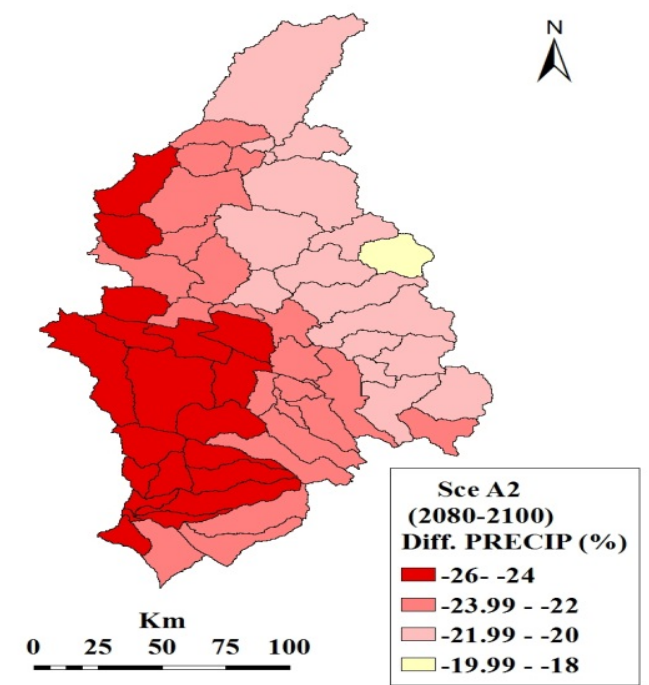

(b)

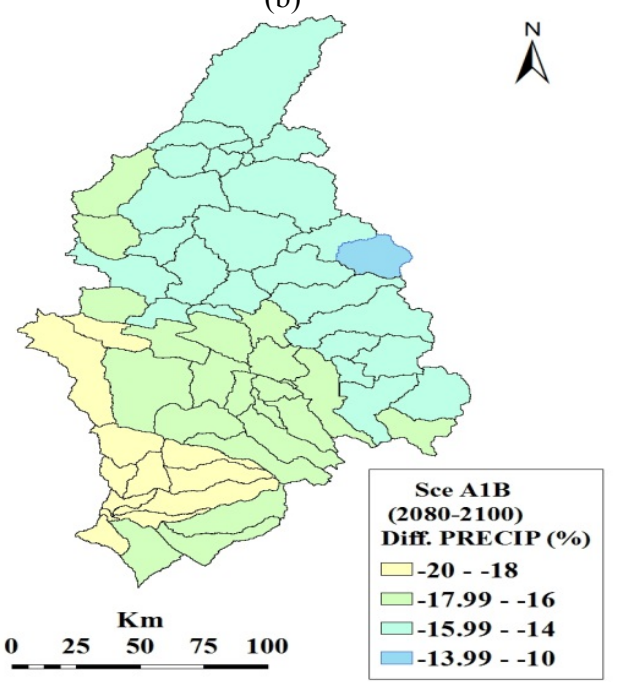

(d)

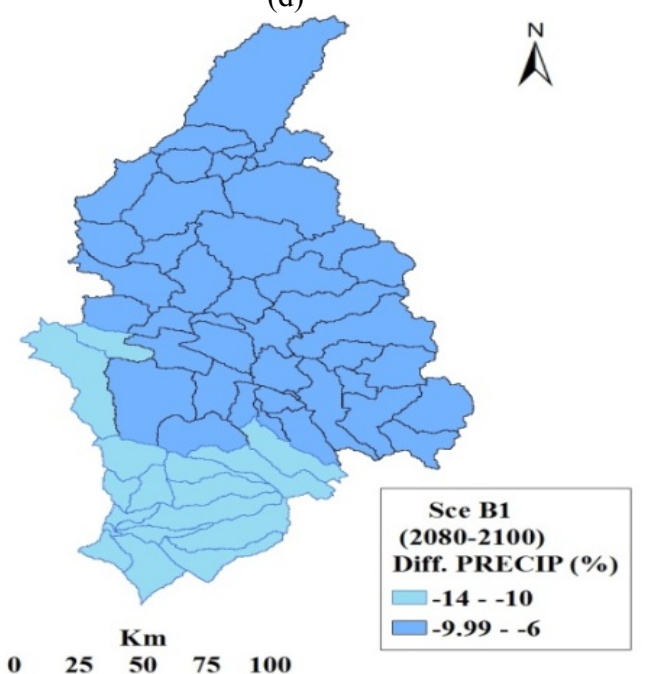

(f)

Fig. 11 The impacts of climate change on the precipitation of the basin: (a) anomaly based on Scenario A2 for the period of 2046 2064; (b) anomaly for A2 to 2080 2100; (c) anomaly for A1B to 2046 2064; (d) anomaly for A1B to 2080 2100; (e) Anomaly for B1 to 2046 2064; (f) anomaly for B1 to 2080 2100. 


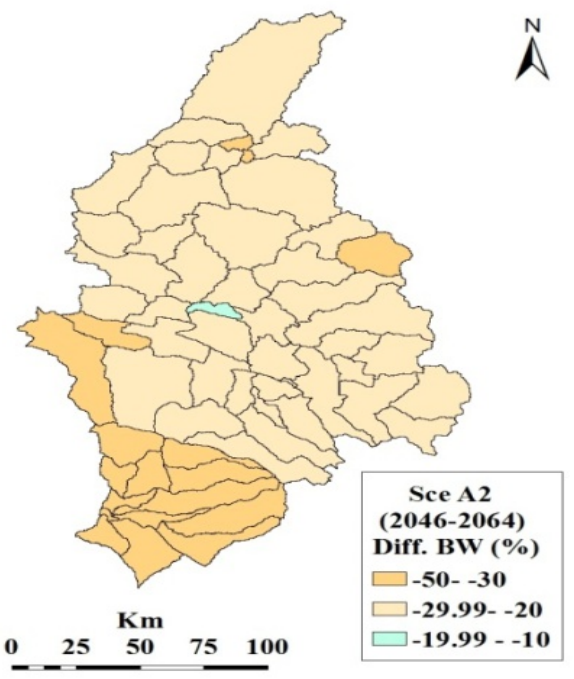

(a)

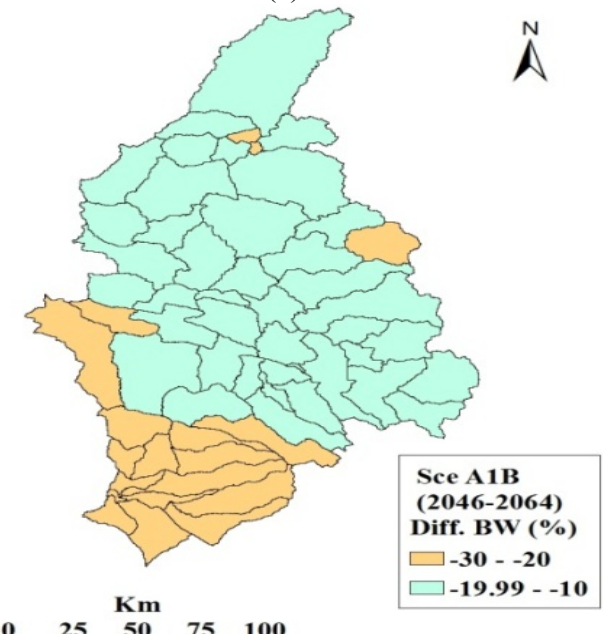

(c)

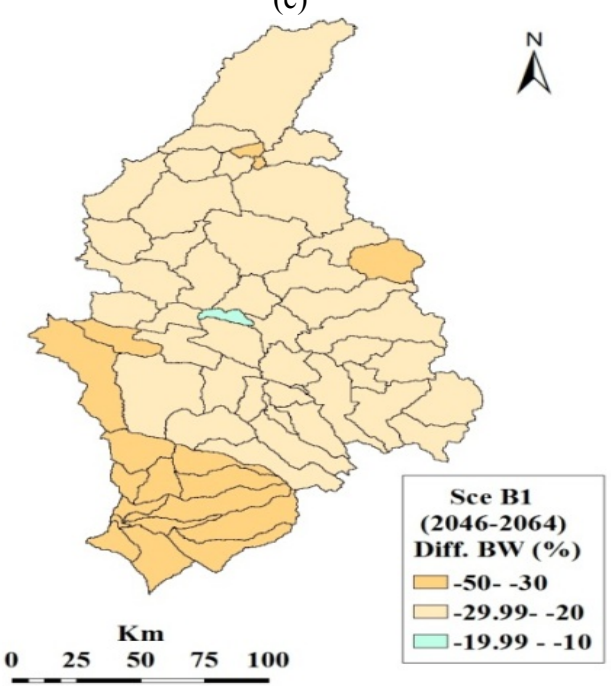

(e)

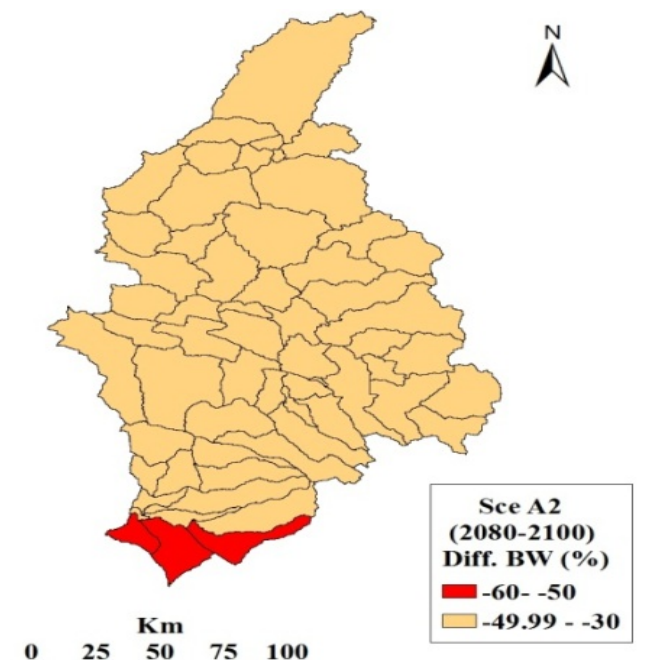

(b)

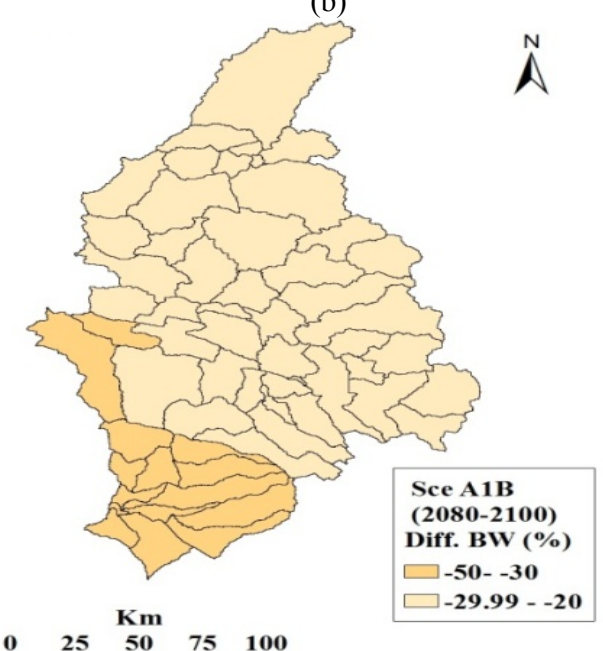

(d)

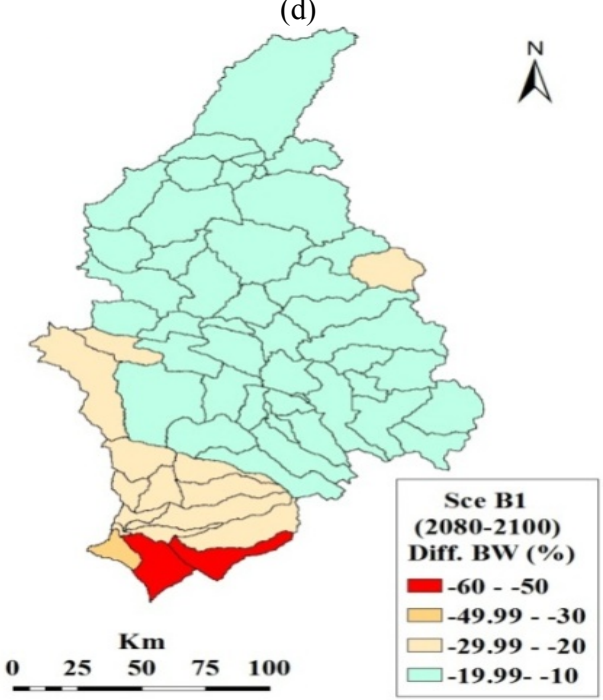

(f)

Fig. 12 The impacts of climate change on the blue water of the basin: (a) anomaly based on Scenario A2 for the period of 2046 2064; (b) anomaly for A2 to 2080 2100; (c) anomaly for A1B to 2046 2064; (d) anomaly for A1B to 2080 2100; (e) anomaly for B1 to 2046 2064; (f) anomaly for B1 to 2080 2100. 


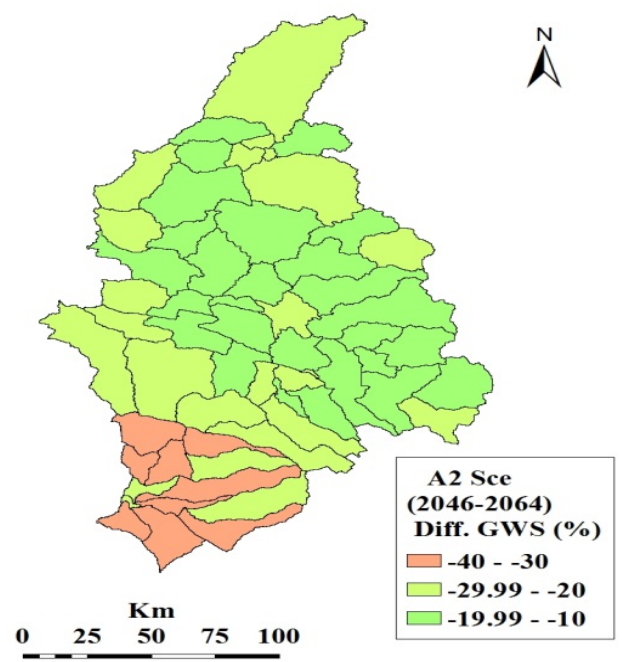

(a)

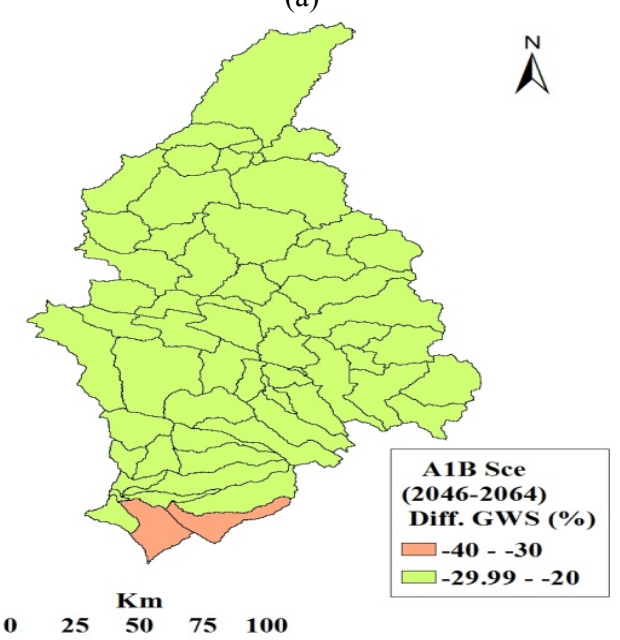

(c)

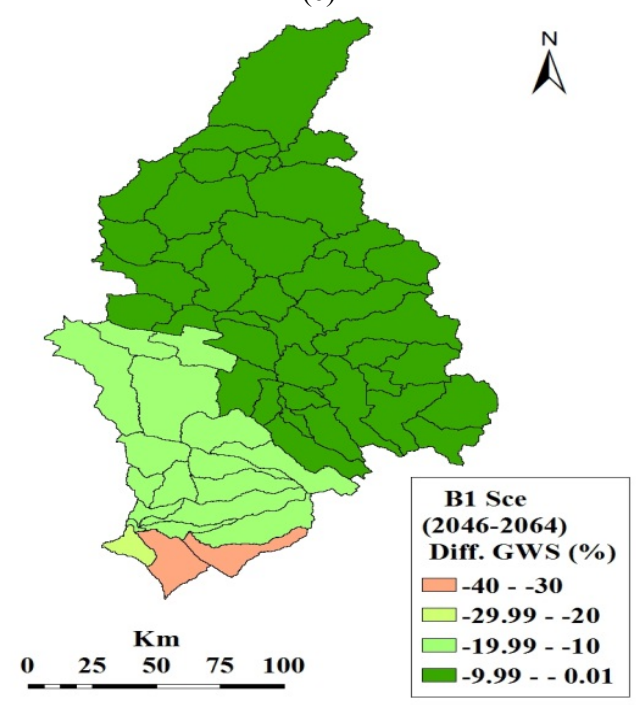

(e)

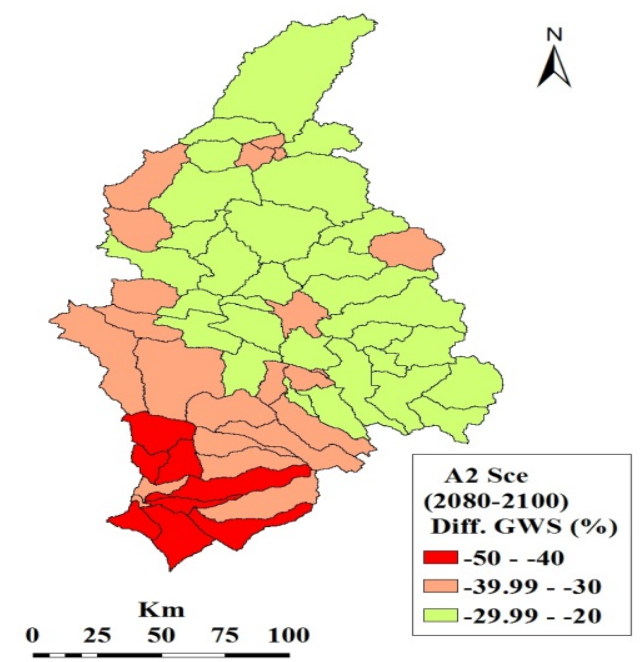

(b)

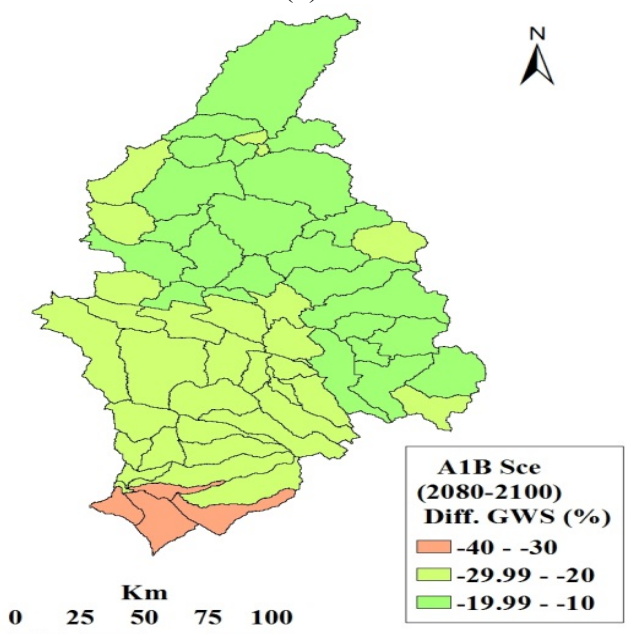

(d)

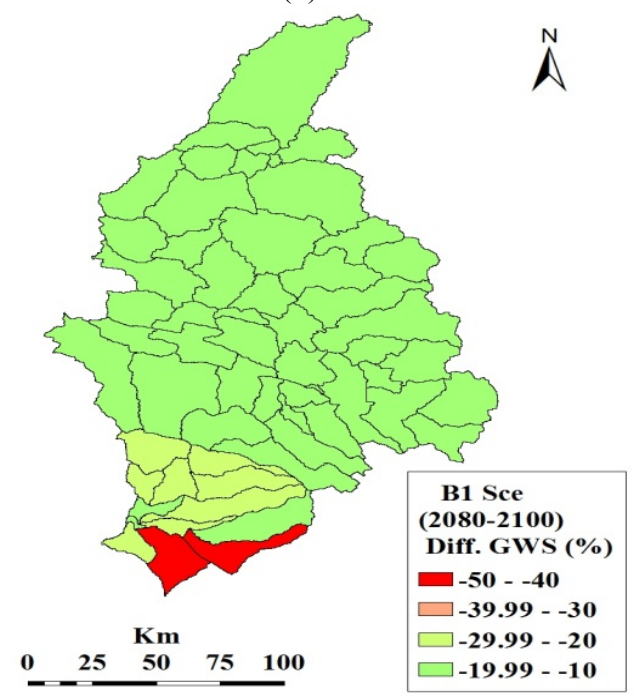

(f)

Fig. 13 The impacts of climate change on the green water storage of the basin: (a) anomaly based on Scenario $\mathrm{A2}$ for the period of 2046 2064; (b) anomaly for A2 to 2080 2100; (c) anomaly for A1B to 2046 2064; (d) anomaly for A1B to 2080 2100, (e) anomaly for B1 to 2046 2064; (f) anomaly for B1 to 2080 2100. 


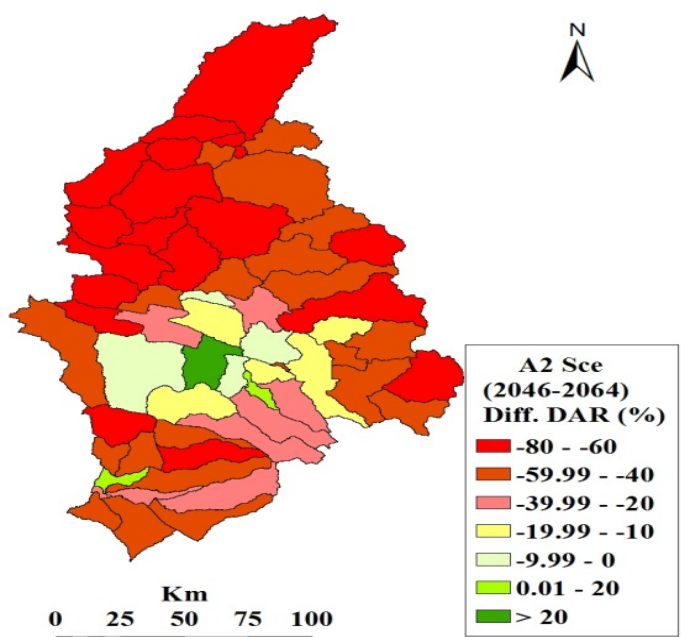

(a)

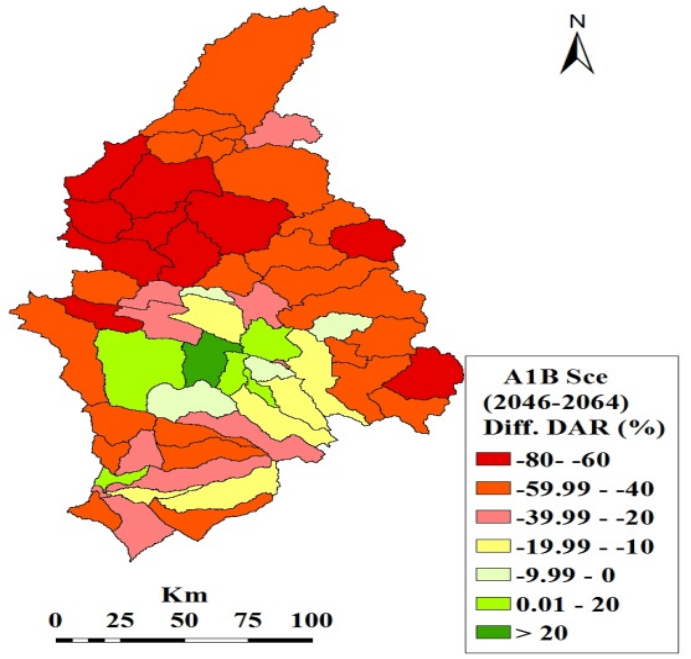

(c)

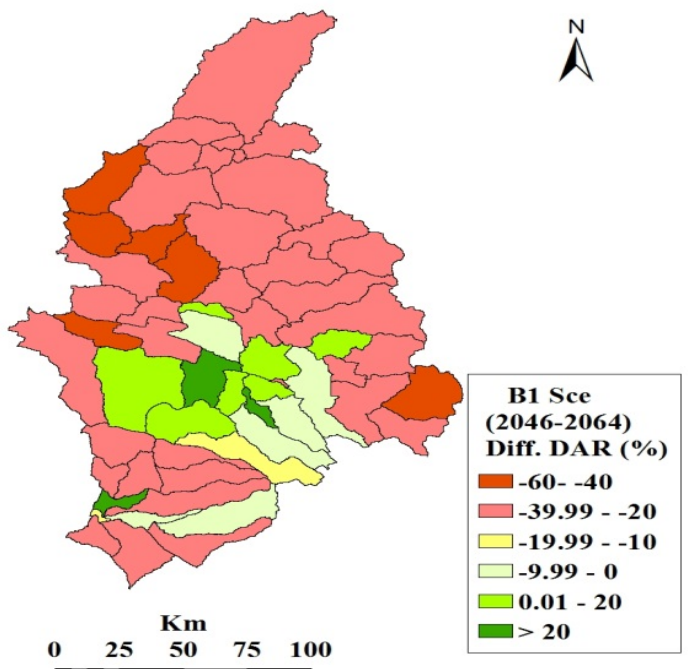

(e)

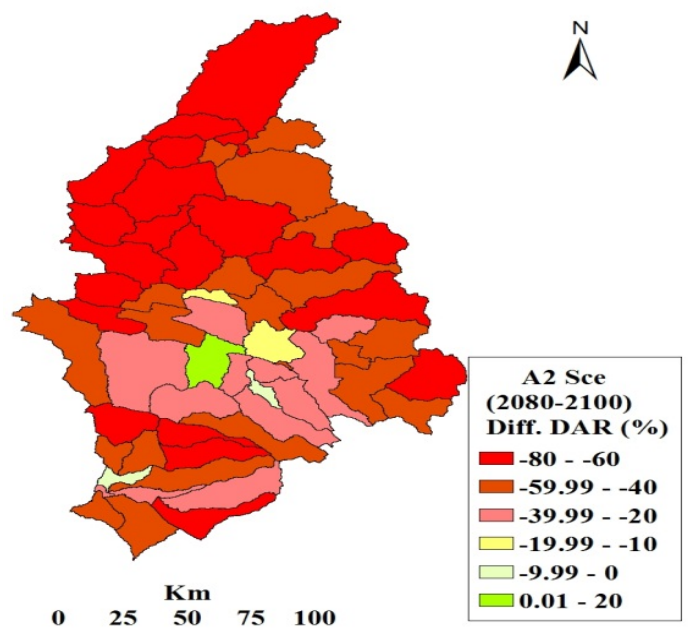

(b)

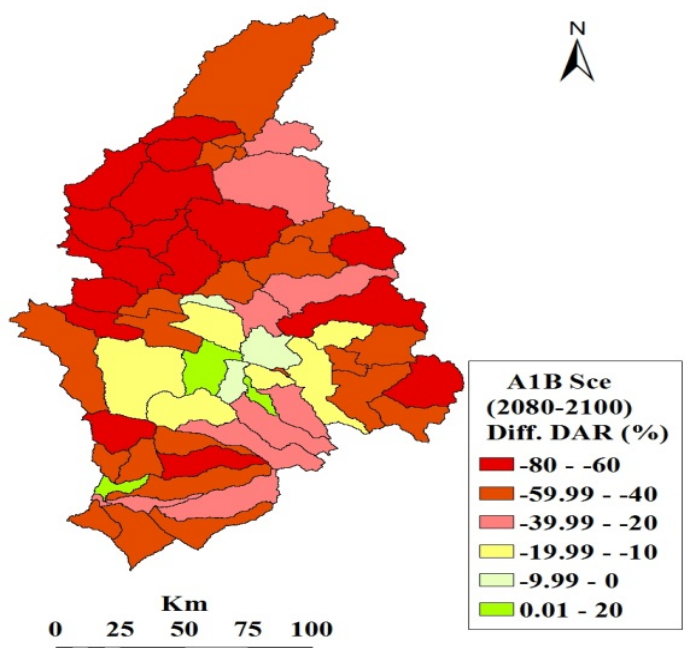

(d)

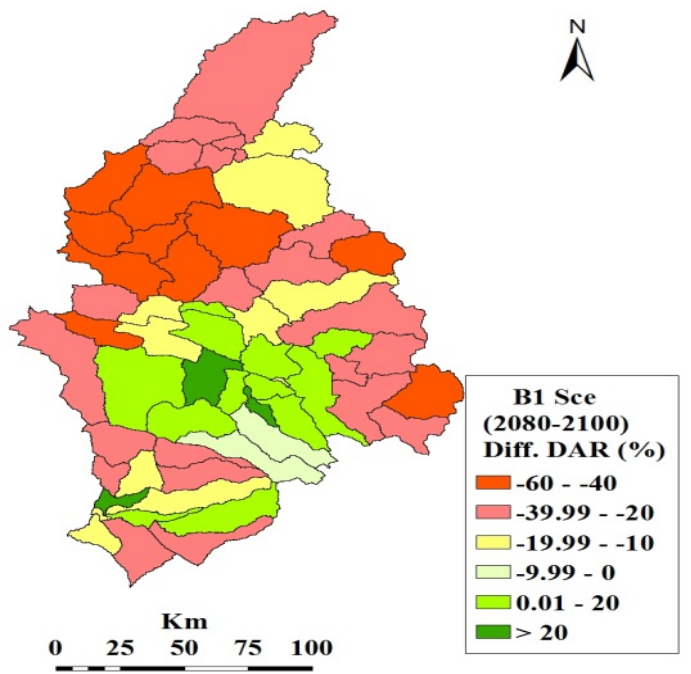

(f)

Fig. 14 The impacts of climate change on the deep aquifer recharge of the basin: (a) anomaly based on Scenario A2 for the period of 2046 2064; (b) anomaly for A2 to 2080 2100; (c) anomaly for A1B to 2046 2064; (d) anomaly for A1B to 2080 2100; (e) anomaly for B1 to 2046 2064; (f) anomaly for B1 to 2080 2100. 
for both periods. The half-century projection (2046 2064) will experience average decreases of 16\%, $12 \%$ and $5 \%$ under $\mathrm{A} 2, \mathrm{~A} 1 \mathrm{~B}$ and $\mathrm{B} 1$ scenarios, respectively. In the one-century future, the reductions will increase to $22 \%, 16 \%$ and $10 \%$ under A2, A1B and B1 scenarios, respectively.

The reductions in the lower and the west part of the basin would be quite large, as high as $20 \%$ and $26 \%$ for the half-century future and one-century future, respectively, under extreme A2 emission scenario. As these parts are experiencing low precipitation, the projected decreases could have significant effects on frequent droughts and hence on agricultural productions.

\subsection{Impacts of Climate Change on Blue and Green Water Flows}

Fig. 12 captures the anomaly maps of blue water distribution (maps of percent deviation from historic data, 1980 2010) for A2, A1B and B1 scenarios for the periods 2046 2064 and 2080 2100 for the average change of multi-GCM ensemble. The half-century projection (2046 2064) will see a decrease in blue water under all emission scenarios for the whole basin. A2 scenario projected the highest reduction $(29 \%)$ followed by A1B $(20 \%)$ and then B1 $(12 \%)$. In the one-century future, the reduction will increase to $38 \%, 29 \%$ and $20 \%$ under A2, A1B and B1 emission scenarios, respectively. Similarly, green water storage will decrease under the three emission scenarios for the two future periods, which is captured in Fig. 13. Green water flow calculations (maps not shown) indicated a slight decrease in evapotranspiration due to assumption that land cover would not significantly change from the period of 1980 to 2010 in the future.

\section{Conclusions}

The model, SWAT was applied to the Greater Zab basin at monthly time steps. The model was calibrated and validated at three discharge stations to simulate the stream flow. The performance of the model was found to be satisfactory with $R^{2}$ and $E N C$ indices during the calibration and validation periods. The calibrated model was used for identifying the trends of water components in the last three decades. Precipitation, blue water, and green water flows were found to significantly decrease from 1980 to 2010 . The findings matched with observations. Next, the model was applied for assessing the impacts of climate change in near and distant futures under three emission scenarios (A2, A1B, B1) using six GCMs. All models run under three emission scenarios predicted that the catchment will be drier in the near and distant futures. The results of this study could be beneficial in identifying appropriate water resources management strategies and cultivation practices of the future.

\section{References}

[1] Arnell, N. W., Vuuren, D. P., and Isaac, M. 2011. "The Implications of Climate Policy for the Impacts of Climate Change on Global Water Resources." Global Environmental Change 21: 592-603.

[2] Beck, L., and Bernauer, T. 2011. "How Will Combined Changes in Water Demand and Climate Affect Water Accessibility in the Zambezi River Basin?." Global Environmental Change 21: 1061-72.

[3] Tong, S. T. Y., Sun, Y., Ranatunga, T., He, J., and Yang, Y. J. 2012. "Predicting Plausible Impacts of Sets of Climate and Land Use Change Scenarios on Water Resources." Applied Geography 32: 477-89.

[4] Gallart, F., Delgado, J., Beatson, S. J. V., Posner, H., Llorens, P., and Marcé, R. 2011. "Analyzing the Effect of Global Change on the Historical Trends of Water Resources in the Headwaters of the Llobregat and Ter River Basins (Catalonia, Spain)." Physics and Chemistry of the Earth 36: 655-61.

[5] Tabari, H., and Willems, P. 2016. "Daily Precipitation Extremes in Iran: Decadal Anomalies and Possible Drivers." Journal of American Water Resources Association 52: 541-99.

[6] Borgomeo, E., Pflug, G., Hall, J. W., and Hochrainer-Stigler, S. 2015. "Assessing Water Resource System Vulnerability to Unprecedented Hydrological Drought Using Copulas to Characterize Drought Duration and Deficit." Water Resources Research 51: 8927-48. 
[7] Mimikou, M. A., Baltas, E., Varanou, E., and Pantazis, K. 2000. "Regional Impacts of Climate Change on Water Resources Quantity and Quality Indicators.” Journal of Hydrology 234: 95-109.

[8] Winter, J. M., and Eltahir, E. A. B. 2012. "Modeling the Hydroclimatology of the Midwestern United States. Part 1: Current Climate." Climate Dynamics 38: 573-93.

[9] Xuan, Z., and Chang, N. B. 2014. "Modeling the Climate-Induced Changes of Lake Ecosystem Structure under the Cascade Impacts of Hurricanes and Droughts." Ecological Modelling 288: 79-93.

[10] Owor, M., Taylor, R. G., Tindimugaya, C., and Mwesigwa, D. 2009. "Rainfall Intensity and Groundwater Recharge: Empirical Evidence from the Upper Nile Basin." Environmental Research Letters 4: 035009.

[11] Chenoweth, J., Hadjinicolaou, P., Bruggeman, A., Lelieveld. J., Levin, Z., Lang, M. A., Xoplaki, E., and Hadjikakou, M. 2011. "Impact of Climate Change on the Water Resources of the Eastern Mediterranean and Middle East Region: Modeled 21st Century Changes and Implications." Water Resources Research 47: 1-18.

[12] Al-Ansari, N., Ali, A. A., and Knutsson S. 2014. "Present Conditions and Future Challenges of Water Resources Problems in Iraq." Journal of Water Resource and Protection 6: 1066-98.

[13] IPCC (Intergovernmental Panel on Climatic Change). 2007. Climate Change 2007: Impacts, Adaptation and Vulnerability: Contribution of Working Group II to the Fourth Assessment Report of the Intergovernmental Panel on Climate Change. Cambridge: Cambridge University Press.

[14] UN-ESCWA (United Nations Economic and Social Commission for Western Asia), and BGR (Bundesanstaltfür Geowissenschaften und Rohstoffe). 2013. Inventory of Shared Water Resources in Western Asia. Beirut.

[15] Kafia, M. S., Slaiman, G. M., and Nazanin, M. S. 2009. "Physical and Chemical Status of Drinking Water from Water Treatment Plants on Greater Zab River." Journal of Applied Sciences and Environmental Management 13 (3): 89-92.

[16] Issa, I. E., Al-Ansari, N., Sherwany, G., and Knutsson, S. 2014. "Expected Future of Water Resources within Tigris-Euphrates Rivers Basin, Iraq." Journal of Water Resource and Protection 6: 421-32.

[17] Abdulla, F., and Al-Badranih, L. 2000. "Application of a Rainfall-Runoff Model to Three Catchments in Iraq." Hydrological Sciences Journal 45: 13-25.

[18] Arnold, J. G., Srinivasan, R., Muttiah, R. S., and Williams, J. R. 1998. "Large Area Hydrologic Modeling and
Assessment Part I: Model Development 1." Journal of the American Water Resources Association 34 (1): 73-89.

[19] Neitsch, S. L., Arnold, J. G., Kiniry, J. R., Williams, J. R., and King, K. W. 2005. Soil and Water Assessment Tool Theoretical Documentation. Version 2000. Texas: Texas Water Resource Institute, College Station.

[20] Green, W. H., and Ampt, G. A. 1911. "Studies on Soil Physics." Journal of Agricultural Science 4: 1-24.

[21] Monteith, J. L. 1965. "Evaporation and the Environment, in the State and Movement of Water in Living Organisms." Symposia of the Society of Experimental Biology 19: 205-34.

[22] Priestley, C. H. B, and Taylor, R. J. 1972. "On the Assessment of Surface Heat Flux and Evaporation Using Large-Scale Parameters." Bulletin of American Meteorological Society 100: 81-92.

[23] Hargreaves, G. L., Hargreaves, G. H., and Riley, J. P. 1985. “Agricultural Benefits for Senegal River Basin.” Journal of Irrigation and Drainage Engineering 111: 113-24.

[24] FAO (Food and Agriculture Organization of the United Nations). 1995. The Digital Soil Map of the World and Derived Soil Properties. Version 3.5. Rome: Food and Agriculture Organization of the United Nations.

[25] Abbaspour, K. C., Yang, J., Maximov, I., Siber, R., Bogner, K., Mieleitner, J., Zobrist, J., and Srinivasan, R. 2007. "Modelling Hydrology and Water Quality in the Pre-alpine/Alpine Thur Watershed Using SWAT." Journal of Hydrology 333: 413-30.

[26] Yang, J., Reichert, P., Abbaspour, K. C., Xia, J., and Yang, H. 2008. "Comparing Uncertainty Analysis Techniques for a SWAT Application to the Chaohe Basin in China." Journal of Hydrology 358: 1-23.

[27] Schuol, J., and Abbaspour, K. C. 2007. "Using Monthly Weather Statistics to Generate Daily Data in a SWAT Model Application to West Africa." Ecological Modelling 201: 301-11.

[28] Nash, J. E., and Sutcliffe, J. V. 1970. "River Flow Forecasting through Conceptual Models Part I-A Discussion of Principles." Journal of Hydrology 10: 282-90.

[29] Legates, D. R., and McCabe, G. J. 1999. "Evaluating the Use of 'Goodness-of-Fit' Measures in Hydrologic and Hydroclimatic Model Validation.” Water Resources Research 35: 233-41.

[30] Moriasi, D. N., Arnold, J. G., Van Liew, M. W., Bingner, R. L., Harmel R. D., and Veith, T. L. 2007. "Model Evaluation Guidelines for Systematic Quantification of Accuracy in Watershed Simulations." Transactions of the ASABE 50: 885-900.

[31] Santer, B. D., Taylor, K. E., Wigley, T. M., Penner, J. E. , Jones, P. D., and Cubasch, U. 1995. "Towards the Detection and Attribution of an Anthropogenic Effect on 
Climate." Journal of Climate Dynamics 12: 77-100.

[32] Hegerl, G. C., Vonstorch, H., Hasselmann, K., Santer, B. D., Cubasch, U., and Jones, P. D. 1996. "Detecting Greenhouse-Gas-Induced Climate Change with an Optimal Fingerprint Method." Journal of Climate 9: 2281-306.

[33] ASCE (American Society of Civil Engineers). 1993. "Criteria for Evaluation of Watershed Models." Journal of Irrigation and Drainage Engineering 119: 429-42.

[34] Raghavan, S. V., Tue ,V. M., and Shie-Yui, L. 2014. "Impact of Climate Change on Future Stream Flow in the Dakbla River Basin." Journal of Hydroinformatics 16: 231-44.

[35] Al-Mukhtar, M., Dunger, V., and Merkel, B. 2014. "Assessing the Impacts of Climate Change on Hydrology of the Upper Reach of the Spree River: Germany." Water Resources Management 28: 2731-49.

[36] Maurer, E. P., Brekke, L., Pruitt, T., Thrasher, B., . Long, J., Duffy, P., Dettinger, M., Cayan, D., and Arnold, J. G. 2014. "An Enhanced Archive Facilitating Climate Impacts and Adaptation Analysis." Bulletin of the American Meteorological Society 95: 1011-19.

[37] Li, Z., Xu, Z., Shao, Q., and Yang, J., 2009. "Parameter Estimation and Uncertainty Analysis of SWAT Model in Upper Reaches of the Heihe River Basin." Hydrological Processes 23: 2744-53.

[38] Cibin, R., Sudheer, K. P., and Chaubey, I. 2010. "Sensitivity and Identifiability of Stream Flow Generation Parameters of the SWAT Model." Hydrological Processes 24: 1133-48.

[39] Rijsberman, F. R. 2006. "Water Scarcity: Fact or Fiction?." Agricultural Water Management 80: 5-22.

[40] Falkenmark, M. 1989. "The Massive Water Scarcity Now Threatening Africa: Why isn't it being Addressed?." Ambio 18: 112-8.

[41] Zang, C. F, Liu, J., Velde, M., and Kraxner, F. 2012. "Assessment of Spatial and Temporal Patterns of Green and Blue Water Flows under Natural Conditions in Inland River Basins in Northwest China." Hydrology and Earth System Sciences 16: 2859-70. 